\title{
Sechiisland: arte e cotidiano de uma ilha imaginária ${ }^{1}$
}

\section{Sechiisland: art and everyday life of an imaginary island}

\author{
Rodrigo Emanoel Fernandes²; Marta Dantas ${ }^{3}$
}

\begin{abstract}
Resumo
O artista plástico José Roberto Sechi tornou-se uma figura representativa no cenário da rede internacional de Arte Postal (Mail Art), na qual artistas do mundo todo utilizam o sistema dos correios como suporte para criação e distribuição artística. De seu trabalho como artista postal e de seu desejo de (re)construir sua identidade enquanto artista e ser humano, Sechi pouco a pouco transformou sua casa, localizada num bairro carente da cidade Rio Claro-SP, num centro cultural alternativo, com um significativo acervo de obras catalogadas, espaço para exposições de artistas inseridos nos movimentos experimentais contemporâneos, biblioteca de referência e espaço para encontros. Batizando sua criação de Sechiisland (Ilha Sechi), o artista a define como uma ilha imaginária, que tornou-se uma referência - tão ou mais importante que uma instituição oficializada - para um enorme número de artistas postais do mundo todo. No presente artigo, pretendemos realizar uma primeira aproximação/leitura desse espaço, com o objetivo de evidenciar um processo deliberado de criação de um cotidiano alternativo, entendendo a Sechiisland como uma imagem poética passível de ser lida e apropriada como uma obra de arte em processo, em seu aspecto físico e concreto e/ou em sua representatividade virtual.
\end{abstract}

Palavras-chave: Arte Postal. Sechiisland. Cotidiano Alternativo. Artes Plásticas. País Imaginário. Poesia Visual.

\begin{abstract}
The plastic artist José Roberto Sechi has become a representative figure in the scenario of the Mail Art international network in which artists of the whole world make use of the Mail System as a support for creation and artistic distribution. From his work as a mail artist and his desire to (re)construct his identity as an artist and a human being, Sechi transformed his house, located in a poor neighborhood of the city of Rio Claro - SP, little by little, into an alternative cultural center, with a significant collection of catalogued art works, a space for exhibition of artists inserted into contemporary experimental movements, a reference library and a space for meetings. Naming his creation as Sechiisland (Island Sechi), the artist defines it as an imaginary island that has become a reference - so or more important than an official institution - for a great number of mail artists worldwide. In this present article, it is intended to carry out a first approach/reading of this space, with the purpose of evidencing a deliberate process of creation of an alternative everyday life, understanding Sechiisland as a poetic image, susceptible of being read as well as borrowed as a work of art in process, in its physical and concrete aspect and/or in its virtual representativeness.
\end{abstract}

Key words: Mail Art. Sechiisland. Daily Life Alternative. Visual Arts. Imaginary Country. Visual Poetry.

\footnotetext{
1 Este artigo é resultado de um sub-projeto de Iniciação Cientifica vinculado ao projeto Infames, casos de singularidade histórica.

2 Aluno do $3^{\circ}$ ano do curso de Artes Cênicas da UEL, bolsista do PROIC/UEL.

3 Professora Doutora de História e Teorias da Arte do Departamento de Arte Visual e do Programa de Pós-Graduação em Letras da UEL.
} 


\section{Introdução}

$\mathrm{O}$ presente artigo originou-se de um desdobramento do projeto "Infames, Casos de Singularidade Histórica" e, como tal, teve como ponto de partida aprofundar a busca dessas forças que transgridem o ideal gregário e o processo de domesticação do ser elaborado por ele (GIANNATTASIO, 2004).

Para além de dissecar a vida e a obra de renomados "infames" históricos, fazia-se necessário o estudo de figuras contemporâneas, verdadeiramente anônimas, porém acessíveis ao pesquisador. Não meramente como "objetos de estudos", o que não deixa de ser um tanto quanto indigno, mas como parceiros de uma busca. O que nos leva a um homem chamado José Roberto Sechi, morador de Rio Claro, interior de São Paulo. Temos aqui o "infame" que, mais do que mero exemplo, torna-se uma referência plenamente integrada aos objetivos dessa pesquisa.

Artista plástico, dono de uma significativa obra que inclui pinturas, esculturas e um elaborado misto das duas linguagens materializado na forma de várias séries de pinturas tridimensionais, teve trabalhos selecionados em mais de uma centena de salões de arte, concursos de poesia e antologias literárias, tendo sido premiado 49 vezes. Como quase sempre acontece, tal prestígio no circuito artístico não se refletiu, nem remotamente, em reconhecimento profissional e muito menos financeiro. Sechi trabalhou como funcionário público dos Correios durante onze anos, até decidir abandonar tudo e viver exclusivamente em prol de seu trabalho artístico, sobrevivendo com os encargos trabalhistas advindos de sua demissão. Uma opção radical, raramente compreendida por amigos ou familiares, pois não poderia jamais ser considerada uma "carreira" ou mesmo um "trabalho" no sentido capitalista do termo, uma vez que, além de não oferecer nenhum ganho financeiro (exceto em raríssimas ocasiões), ainda constitui uma fonte constante de gastos.

$\mathrm{Na}$ verdade, tal opção é um reflexo da própria forma como Sechi encara o conceito de arte. Seu trabalho não é, de forma alguma, um hobby, não se trata de uma atividade secundária que serve como válvula de escape para uma ocupação socialmente aceitável em primeiro plano. Nem, muito menos, um gradativo aperfeiçoamento de uma técnica que extrapola o ato criador em si e acaba reduzindo o fazer artístico a uma atividade mecânica, um apaziguamento da mente por demais sufocada pelo ritmo cotidiano. Para Sechi, arte é a vida, uma forma de dialogar com o mundo, uma alternativa de leitura da realidade, nunca fechada, nunca enquadrada, um constante "viver" artístico com inúmeros desdobramentos, entre os quais um aprofundado pensamento teórico e filosófico sobre a arte em si. No objetivo de "viver" verdadeiramente sua arte, Sechi remodelou seu próprio espaço vital e suas relações com o mundo exterior, e desenvolveu um projeto artístico que não deixa de ser um projeto de vida. E é nesse ponto que Sechi torna-se particularmente significativo para os interesses desse trabalho.

Os tempos de funcionário público permitiram a Sechi aprofundar seus contatos com o movimento da Arte Postal (Mail Art), um atuante sistema estratégico de intercâmbio artístico, no qual envelopes, cartões, selos, pacotes, carimbos, etc. tornam-se obras de arte ou veículos para obras de arte. O sistema internacional dos correios torna-se o suporte privilegiado para manifestações artísticas que cruzam fronteiras, trocam de mãos, reproduzemse, quebram barreiras de idiomas e culturas e criam uma vasta rede de intercomunicação entre artistas de todo o mundo. Anônimos, na maioria, ausentes da mídia, invisíveis para o mundo dos não-engajados na arte, mas extremamente presentes como forças políticas, estéticas e ideológicas nesse imenso caldo cultural underground.

O envolvimento de Sechi com a Arte Postal que, mais do que mero participante, alcançou o status de importante teórico do movimento, ainda que extra-academicamente - fortaleceu os laços com artistas do mundo todo, o que permitiu que fizesse de sua própria casa um verdadeiro centro cultural, armazenando cuidadosamente um gigantesco número de obras de Arte Postal, além de um banco 
de dados artísticos tão cuidadosamente organizado quanto um pequeno museu. Obras não param de chegar e partir, inspirando o artista a transformar a própria casa num espaço alternativo para exposições e manifestações artísticas. Nasceu assim o Projeto Sechiisland que, nas palavras de seu criador, "é um país imaginário, uma ilha fantástica, um estado de espírito, um projeto de arte conceitual".

O projeto abarca, entre outras iniciativas, a revista Pense Aqui - Think Here, uma publicação artesanal dedicada à divulgação e documentação de obras de Arte Postal, a Sechiisland's Micro Gallery, um espaço destinado à pequenas exposições individuais de artistas cujos trabalhos têm em comum o fato de estarem inseridos nos movimentos experimentais artísticos e literários surgidos a partir da década de sessenta do século XX até os dias atuais, e a Sechiisland's International Library, uma biblioteca especializada em arte e publicações alternativas que, desde sua divulgação em março de 2003, recebe, diariamente, livros, revistas, catálogos, zines, publicações experimentais, livros de artista, vídeos, CDs, CD-ROMs, DVDs, textos e outras informações advindas da enorme rede de artistas postais do mundo todo.

A execução de todas essas atividades, como já salientado, não é destinada nem à "horas livres" e nem a um certo "horário de trabalho", mas sim constitui-se um cotidiano, que poderia ser chamado "alternativo" numa perspectiva geral. Esse cotidiano é simplesmente habitual para Sechi, enquanto indivíduo. Resultado de uma deliberada "construção" de um modo de vida em contraponto a uma cotidianidade continuamente questionada e jamais vista como "natural". O estabelecimento desse "cotidiano", como não poderia deixar de ser, acaba tornando-se um permanente enfrentamento com o cotidiano naturalizado e, independente de quaisquer ideais ou objetivos do artista, resulta numa espécie de "banimento" das esferas sociais habituais. Embora Sechi seja, certamente, um artista e pensador respeitado nos círculos artísticos, na malha da Arte Postal e entre um certo punhado de amigos mais ou menos "infames", perante os habitantes da cidade de Rio Claro/SP e mais especificamente do bairro Jardim São João (um bairro de periferia, habitado por uma população majoritariamente de baixa renda e escolaridade) Sechi é apenas um sujeito "esquisito", pouco representativo e ausente dos caminhos normais da comunidade e sua Sechiisland não passa de um insuspeitado sobrado nem um pouco diverso das demais habitações do bairro.

Nessa perspectiva, Sechi surge como um legítimo "infame" segundo os parâmetros desse projeto, uma figura ímpar, cujo aprofundamento biográfico e devida compreensão da obra em seus múltiplos aspectos já são, por si só, interessantes o suficiente para justificar uma pesquisa cuidadosa. Entretanto, para além da pessoa do artista, Sechi nos oferece uma oportunidade de extrapolar a intenção de criar um "banco de dados" de figuras "infames" contemporâneas visto que esse banco de dados já existe e localiza-se num país imaginário chamado Sechiisland, acessível à visitação e à pesquisa, passível de se tornar uma ponte para todo um universo de singularidades, com suas discordâncias, contradições, visões de mundo e possibilidades.

Nesse contexto tão amplo, o presente artigo se apresenta meramente como uma primeira aproximação. Seu objetivo é introduzir o leitor nesse microcosmo chamado Sechiisland, apresentar para olhos leigos a amplitude, o alcance e a complexidade dessa "ilha" que é, ao mesmo tempo, um homem. Para tanto, o artigo foi organizado como uma "visita", que nada mais é do que uma primeira leitura desse espaço, visto como uma obra de arte em andamento por si só, uma imagem poética, como entendida por Gaston Bachelard:

A imagem poética [...] não é o eco de um passado. É antes o inverso: com a explosão de uma imagem, o passado longínquo ressoa de ecos e já não vemos em que profundezas esses ecos vão repercutir e morrer. Em sua novidade, em sua atividade, a imagem poética tem um ser próprio, um dinamismo próprio. [...] Portanto, é quase sempre no inverso da causalidade, na repercussão, [...] que acreditamos encontrar as 
verdadeiras medidas do ser de uma imagem poética. Nessa repercussão, a imagem poética terá uma sonoridade de ser. O poeta fala no limiar do ser. Assim sendo, para determinarmos o ser de uma imagem teremos de sentir a sua repercussão. (BACHELARD, 1993, p. 2).

Portanto, nessa leitura da Sechiisland, embora estejam presentes as informações biográficas necessárias acerca de seu criador, bem como o histórico das origens e desenvolvimento da obra em si, procuraremos evitar a análise excessivamente exaustiva dessas informações. Preferimos abordar apenas os aspectos que se revelarem úteis para que o visitante/leitor possa melhor sentir essa "repercussão"daIlha Sechi enquantoimagempoética e evitar, assim, que elucubrações desnecessárias acerca de causas e efeitos, análises psicológicas e psicanalíticas à pessoa do artista, acabem ofuscando a ressonância que a obra tem por si mesma, em sua própria atualidade poética, sua existência concreta.

[...] as causas alegadas pelo psicólogo e pelo psicanalista jamais podem explicar bem o caráter realmente inesperado da imagem nova, nem tampouco a adesão que ela suscita numa alma alheia ao processo de sua criação. $O$ poeta não me confere $o$ passado de sua imagem, e no entanto ela se enraíza imediatamente em mim. [...] Podemos decerto, em pesquisas psicológicas, dar atenção aos métodos psicanalíticos para determinar a personalidade de uma poeta; podemos encontrar assim uma medida das pressões - sobretudo da opressão - que um poeta teve de sofrer no curso de sua vida; mas o ato poético, a imagem repentina, a chama do ser na imaginação, fogem a tais indagações. (BACHELARD, 1993, p.2, grifo nosso).

Ao final do artigo, espera-se que fique claro ao leitor como essa imagem poética, originada de um cotidiano alternativo, desenvolveu-se até ganhar, efetivamente, uma vida própria. Como o homem,
José Roberto Sechi, de certa forma recriou sua própria identidade em relação ao mundo, indo da figura do artista/marginal/infame até o conceito da Ilha Sechi, o país imaginário reconhecido por centenas de artistas no mundo todo como uma referência, tão ou mais significativa quanto qualquer instituição oficial.

\section{Um farol ao longe: uma pequena história da Sechiisland}

Sechiisland é um país imaginário, uma ilha fantástica, um estado de espirito, um projeto de arte conceitual. (SECHI, 2000, p.1)

Essas foram as palavras que Sechi usou para definir sua criação num manifesto escrito em meados de 2001 e veiculado em inúmeros zines, cartas, e-mails, sites e demais meios de comunicação alternativos. O termo arte conceitual evidencia a importância de se compreender a Sechiisland, antes de tudo, como uma idéia, um conceito, extrapolando assim seus limites meramente físicos. É evidente que essa existência física é de suma importância, até porque será principalmente através dela que realizaremos nossa primeira leitura, porém faz-se necessário compreender, inicialmente, a extensão alcançada pelo conceito, afinal a grande maioria dos indivíduos que se relacionam com a Sechiisland jamais a visitaram e, possivelmente, nunca o farão.

Para esclarecer esse ponto, devemos aprofundar as definições e características da chamada Arte Postal, um dos movimentos artísticos mais importantes do final do século XX e que, até hoje, continua forte, versátil e abrangente, embora - e nisso não há paradoxo - seja praticamente desconhecido nos canais de comunicação oficiais. 


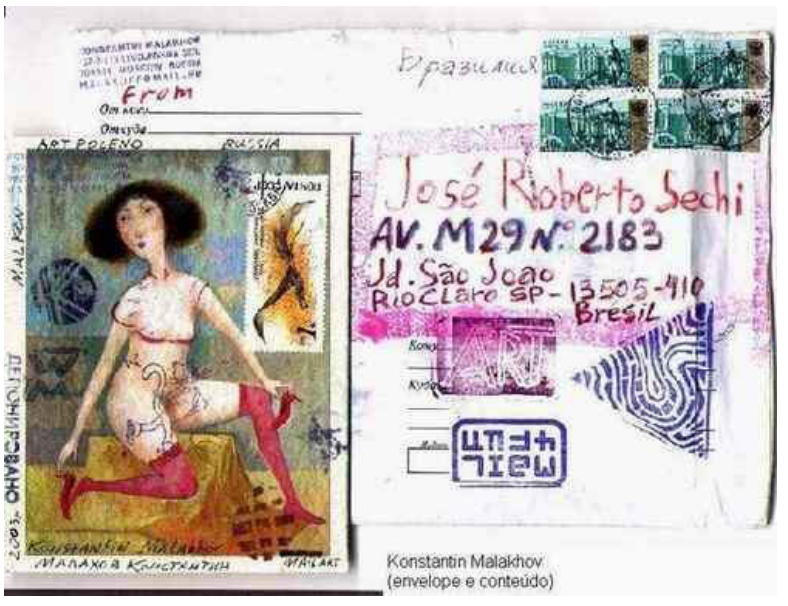

Figura 1. Envelope de autoria de Konstantin Malakhov, Rússia; um exemplo típico de um trabalho de Arte Postal

A troca de material artístico via correio é uma atividade bastante antiga, os futuristas e dadaístas já enviavam poemas por correspondência desde o início do século XX, mas foi a partir do trabalho de Ray Johnson, na década de 60, que o sistema internacional dos Correios passou a ser utilizado não como um meio, mas sim como o próprio suporte da criação. Todo e qualquer elemento que faça parte do sistema (envelopes, cartões, selos, carimbos, etc) é apropriado pelos artistas postais e convertido em matéria prima para a produção das mais variadas formas de expressão (Figura 1). No entanto, é na própria passagem da obra pelo sistema em si, com toda a parafernália de etapas que qualquer correspondência deve passar no interior da instituição (postagem, triagem, distribuição, carteiros, enfim) que o fenômeno da Arte Postal se realiza. Em essência, Arte Postal é comunicação, incontrolável e "sistematicamente caótica", poderiase dizer.
Em termos práticos, o artista A faz alguma alteração (desenho, colagem, texto, etc.) numa folha de papel ou no próprio envelope e envia ao artista $\mathrm{B}$, que recebe o trabalho, altera-o de alguma forma, reproduz e envia uma cópia de volta ao artista $\mathrm{A}$ e outra ao artista $\mathrm{C}$, que continua o processo.

Esse procedimento simples - conhecido como Altere/Passe - foi uma das primeiras experiências com Arte Postal que Ray Johnson pôs em prática nos anos 60 e até hoje é bastante utilizado em todas as suas possíveis variantes. Mas a simplicidade é apenas aparente. O trabalho original irá se reproduzir em escala geométrica, transformandose em algo do qual nenhum de seus "autores" têm o menor controle. Em algum momento um artista poderá acrescentar colagens ao desenho, outro pode transforma-lo num cartão postal, um outro poderá sela-lo com um selo de artista, outro poderá incorporar uma escultura e despacha-la como uma encomenda, o seguinte talvez decida xerografar a obra, o próximo talvez a transforme numa serigrafia, e um determinado artista pode, simplesmente, pôr fogo em tudo e enviar as cinzas para o artista seguinte. E pode muito bem acontecer do criador da obra original receber um dia uma das infinitas variações e sequer reconhece-la como um trabalho seu (Figura 2A e 2B). Nesse ponto, é possível que ele já esteja tentando utilizar o suporte de maneira mais sofisticada e decida colocar o endereço de seu próximo interlocutor no remetente, e enviar o trabalho para um endereço inexistente na Áustria, fazendo o trabalho viajar dentro do sistema dos Correios até ser "devolvido" para o remetente que, na verdade, é o destinatário. 

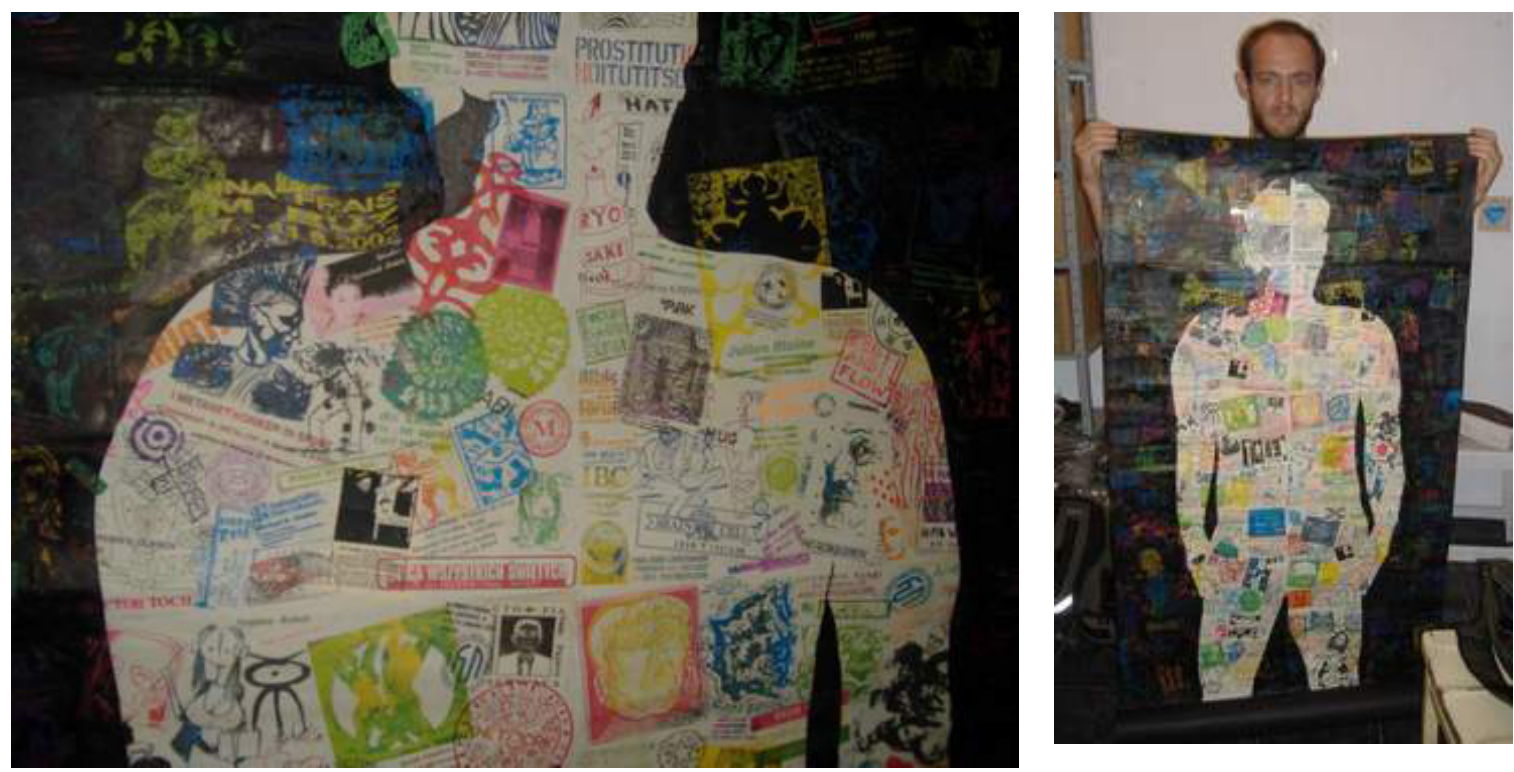

Figura 2. Brain Cell - Fractal, do artista japonês Ryosuke Cohen, obra composta por milhares de fragmentos de trabalhos de Arte Postal recebidos e alterados pelo artista.

Já é possível perceber que a Arte Postal coloca em xeque a própria questão da autoria, bem como a fetichização do "objeto de arte", alvo das críticas de artistas conceituais nos últimos 50 anos. Por mais instigante que seja uma obra, não passa de um resíduo do processo em si - e é desse modo que será encarada em eventuais catálogos, exposições ou arquivos espalhados pelo mundo - pois a realização da Arte Postal se dá no instante em que um artista recebe pelo correio aquilo que outro artista enviou. A formação da rede comunicativa é o foco de todo o processo e não há limites para sua extensão e sua abrangência. A qualquer momento, uma pessoa pode anotar um endereço de uma lista de artistas postais e entrar em contato com a rede meramente enviando uma carta. Não existe um critério de qualidade envolvido, muito menos qualquer tipo de julgamento ou premiação, até porque o gigantismo de todo o processo tornaria tais procedimentos praticamente inviáveis. Mas mesmo que não fosse o caso, a Arte Postal tem como uma de suas características mais marcantes a extrapolação do fenômeno contemporâneo de desmaterialização da obra de arte e da figura do artista. Os trabalhos não são criados para durar, mas sim para perderem-se na efemeridade da comunicação imediata, na "voz" que se propaga independentemente dos meios oficiais de autenticação e distribuição. Assim, a apropriação do sistema dos Correios pela Arte Postal ganha uma importância ideológica e política significativa, pois torna-se uma alternativa não apenas ao sistema de galerias e museus mas, principalmente, a toda e qualquer forma de mídia unilateral, cujo controle pertence a pequenos grupos de indivíduos que, por uma razão ou outra, gozam do prestígio e respeito de uma "autenticação oficial". No contexto da Arte Postal, o artista nada mais é do que o indivíduo se expressando, comunicando, criando, seja uma complicada escultura realizada com uma técnica específica laboriosamente aprendida em anos de estudo ou um guardanapo rabiscado num bar durante uma bebedeira, o ato político/artístico de postar o trabalho pelo correio é o mesmo, carregado de significações por si só.

Comecei a trabalhar nos Correios antes de conhecer a Arte Postal. Eu trabalhava com arte desde 1989; em 91, entrei nos Correios; só em 94 eu tive contato com a Arte Postal - por acaso. Eu participava de muitos salóes de arte. Um dia recebi um convite para uma exposição de Arte Postal [...] 
escrevi para os organizadores pedindo que eles me mandassem a ficha de inscrição e o regulamento da exposição. Passou um tempo, eu achei que eles nem tivessem levado meu pedido em consideração. Depois de alguns meses, recebi em casa um catálogo da exposição - e lá estava eu como participante! A única coisa que tinha enviado era uma carta com um pedido de inscrição - e isso foi exposto! Aquela carta já era uma forma de comunicação, e a essência da Arte Postal é comunicação (SECHI: Entrevista Jornal de Londrina 21/08/2005).

Não é exagero afirmar que, nesse contexto, o artista é meramente o indivíduo que assume-se como tal. Não é alguém dotado de um talento único ou que domina uma técnica com maestria, mas sim alguém que exercita uma necessidade intrínseca de expressar-se e comunicar-se. Se o museu, a galeria, a imprensa ou a TV não autenticam tais indivíduos como artistas, estes criam suas próprias instituições, sistemas, veículos e, até mesmo, editoras, gravadoras, países ou mundos para expressarem suas opiniões, críticas, idéias ou necessidades. Nada mais natural para artistas que utilizam como meios de expressão (físicos ou temáticos) virtualmente quaisquer produtos da dita sociedade de massas, desde selos, envelopes, cartões e outros objetos diretamente associados aos correios até embalagens de mercadorias, jornais, lixo industrial, etc. A lista tende ao infinito, passando inclusive por meios tecnológicos mais modernos como fax, xerox, scanners, computadores, internet. Tudo é passível de apropriação, assimilação e crítica pela rede de Arte Postal.
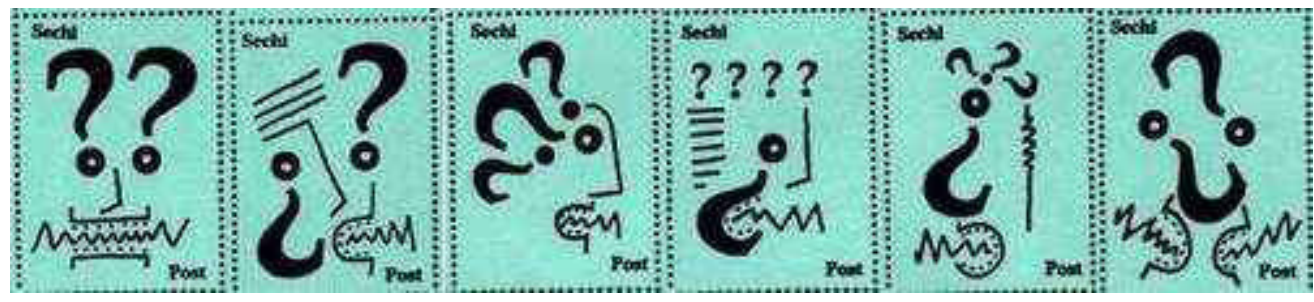

Figura 3. Selos de artista de autoria de José Roberto Sechi

Quando Sechi travou contato com a rede pela primeira vez, já era reconhecido como artista plástico, graças aos prêmios obtidos e de certo reconhecimento perante instituições e seu próprio meio social. Mas tal reconhecimento era insuficiente e, em grande parte, desapontador. As limitações e incompreensões que a grande maioria dos artistas experimentais enfrenta ao lidar com as instituições oficiais, muitas vezes conservadoras de uma forma ou de outra, bem como as burocráticas secretarias municipais de cultura, eram particularmente aflitivas para alguém que, além de artista plástico, também era um profundo autodidata da história da arte, em especial dos movimentos experimentais vanguardistas e contemporâneos. Mas era no aspecto social que as frustrações faziam-se sentir de maneira mais aflitiva. Para Sechi - e, por que não dizer, para muitos artistas em suas origens - a busca pela arte, pela própria identidade de artista, é direta e/ou indiretamente fruto de uma necessidade veemente de socialização que, pelos mais variados motivos, não pode - ou não deseja-se - ser realizada pelos meios habituais da comunidade. Em sua obra inicial, trabalhos realizados entre 1987 e 2001, formada por pinturas (planas, tridimensionais, interativas), esculturas, e mistos experimentais de ambas, é claramente visível sua busca por comunicação, por um elo com seus semelhantes que aliviasse uma carência fundamental por sua identidade enquanto ser humano. Na juventude, Sechi buscou essa identidade das formas que dispunha: freqüentou uma igreja evangélica - da qual sua mãe ainda é devota -, posteriormente, abraçou o marxismo (é de seu costume comentar, jocosamente, que, depois de 
passar por doutrinas tão radicalmente opostas, não tem mais porque se interessar por nenhuma outra forma de "religião"), mas foi com o universo da arte que se identificou verdadeiramente e teve condições de erigir suas bases. Por fim, a Arte Postal permitiu a sistematização de todo um processo de trabalho; os primeiros passos do cotidiano alternativo que viria a ser a essência da Sechiisland.

Nascido no final de 2001, o projeto Sechiisland incorporou atividades artísticas anteriores dentro da militância artecorreista, que iam da rotineira troca de Arte Postal com mail-artistas de todo o planeta e participação em projetos internacionais à edição da revista Pense Aqui, nascida em outubro de 2000. A revista alternativa Pense Aqui é uma espécie de exposição permanente que utiliza como suporte os serviços internacionais de correios ; artistas do mundo todo enviam obras plásticas ou literárias, que são publicadas pela ordem de chegada e uma cópia da revista é imediatamente enviada a cada participante.É um fluxo contínuo de informações e trocas interpessoais. (SECHI, 2000, p.1).

A revista Pense Aqui é um significativo exemplo das publicações alternativas criadas por artistas postais. Sua estrutura é simples e elegantemente funcional: três folhas tamanho A4 (variando apenas as cores a cada edição) dobradas e grampeadas na forma de um caderno de 12 páginas com capacidade para uma média de 18 trabalhos; normalmente dois por página; reproduzidos por meio de xerox. A primeira página estampa o título do periódico ("Pense Aqui - Revista de Arte Postal; Think Here - Mail Art Magazine"), o número da edição e a data de chegada do primeiro e do último trabalho recebidos, além da reprodução de uma obra que servirá de capa. Na segunda página, no verso, consta o número correspondente ao respectivo exemplar $(1 / 25,2 / 25,3 / 25$, etc. ) manuscrito cópia à cópia, o carimbo "Made in Sechiisland" e um trabalho do próprio Sechi. Finalmente, na última página, temos o endereço do remetente - da Sechiisland, portanto - a lista de artistas participantes e seus respectivos países, a reprodução de um selo de artista (Figura 3) e o espaço para o endereço do destinatário de cada exemplar. Uma vez pronta e lacrada para postagem, a revista assume o formato inconfundível de um envelope. A tiragem e periodicidade são variáveis: o fechamento de cada edição se dá com o chegada de um número suficiente de trabalhos para preenche-la; a tiragem é igual ao número de artistas participante,s mais uma pequena sobra para arquivo (Figura 4).

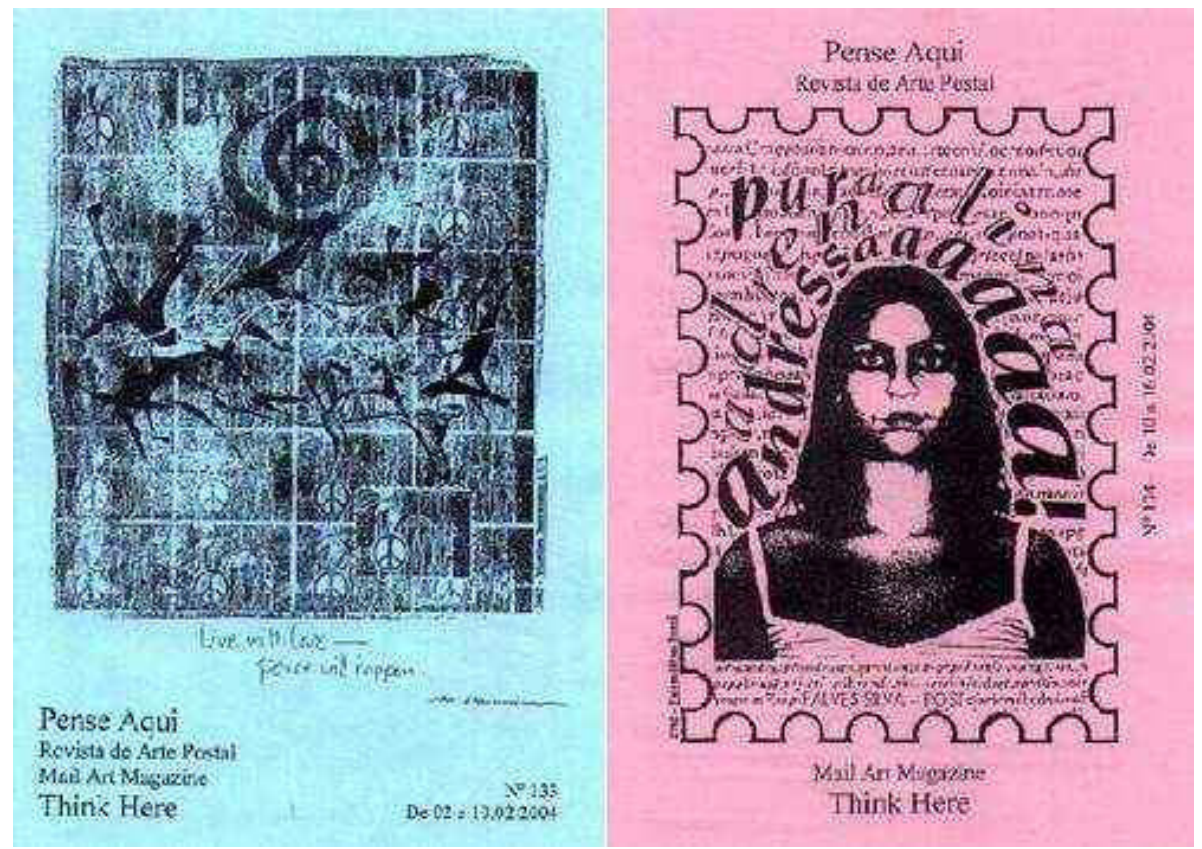

Figura 4. Edições da revista Pense Aqui. 
Embora efemeridade e desapego sejam quase uma filosofia na Arte Postal e boa parte dos artistas postais não mantenha nenhum tipo de registro ou acervo de trabalhos recebidos, fazendo com que poucas obras se fixem numa forma acabada, Sechi diferencia-se por sua natureza de teórico e por uma acentuada tendência à catalogação e sistematização, bem como o desejo de mergulhar da forma mais profunda possível no fenômeno e integra-lo à sua vida pessoal e suas carências e necessidades particulares. A criação da Pense Aqui foi uma conseqüência natural desse processo e ajudou a consolidar sua posição como mais do que um mero participante, mas sim um dos pontos de convergência do fluxo mail-artístico mundial. Por ocasião do primeiro aniversário do periódico (celebrado na edição 31, outubro de 2001) a Pense Aqui já havia publicado 604 obras de Arte Postal, enviadas por 347 artistas de 45 países diferentes. O exemplar mais recente, na data em que este artigo foi redigido, já alcança a impressionante marca de 247 edições e 5353 obras, sendo que todos esses trabalhos encontram-se arquivados por ordem de chegada na Sechiisland.

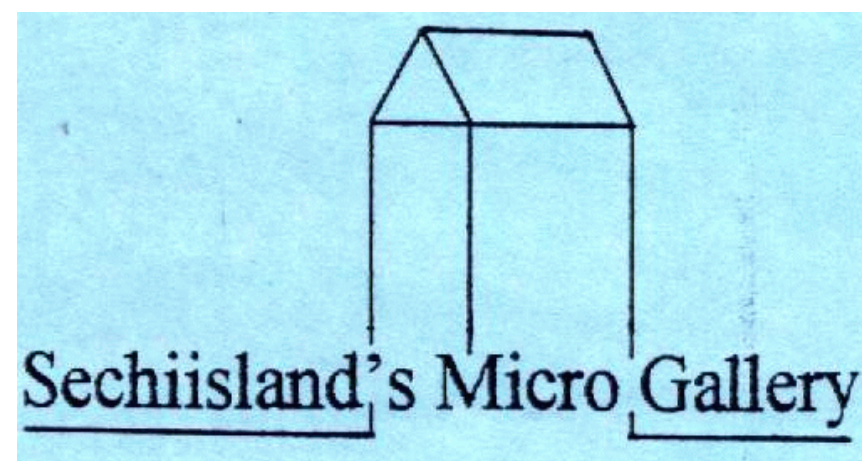

Figura 5. Carimbos da Sechiisland.

Bastou um período de três meses desde o surgimento da Pense Aqui para Sechi ter o estímulo necessário para inaugurar, efetivamente, sua ilha imaginária, nos moldes dos países e instituições fictícias comuns à Arte Postal. Assim como a "Corporación Semiótica Galega" (formada por um único homem) ou a "Expoporc Baudhuin Simon" (na República dos Porcos imaginada pelo artista
Após quase seis anos de atividade e tal volume de trabalhos publicados, a revista tornou-se uma referência importante no cenário da Arte Postal mundial, bem como um veículo eficiente para a divulgação das atividades desenvolvidas na Ilha para um número significativo de artistas. Atualmente, Sechi recebe uma média de 150 correspondências por mês, provenientes de mais de 70 países, a maioria prontamente respondida dando continuidade aos procedimentos mailartísticos. Nos primeiros tempos da revista, Sechi enviava convites para seus interlocutores e para artistas postais mais conhecidos e atuantes; com o tempo esse procedimento tornou-se desnecessário e até arriscado, uma vez que, independente do quão cresça a quantidade de obras, o trabalho continua sendo realizado por um único homem. E não se trata de um trabalho simples, uma vez que não basta fotocopiar as obras, mas sim reproduzi-las de modo a perderem o mínimo de suas características. Além disso, não foram poucas as edições que contaram com encartes de obras originais, como é o caso de séries de selos ou cartões, e adaptações específicas para trabalhos com características particulares.

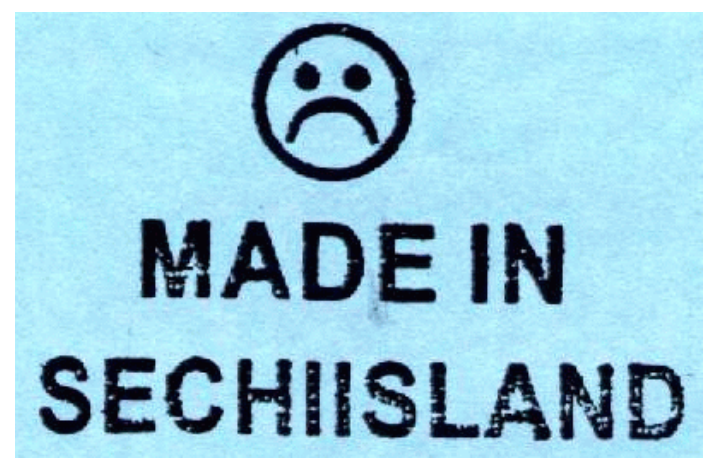

belga Baudhuin Simon), a Sechiisland goza de reconhecimento na rede postal como um lugar real e representativo (Figura 5). Sechi afirma que escolheu o nome por assumir o fato de que sempre se sentiu uma ilha, e é dessa ilha que esse homem, acostumado a poucos amigos e escassa vida social, comunica-se com centenas de interlocutores no planeta inteiro. Essa socialização pela arte foi se 
intensificando conforme a Ilha Sechi materializavase e deixava de ser apenas um conceito, tornando-se um lugar palpável, passível de visitação, incorporado à casa do artista. Ciente desse potencial e ansioso por explorar suas possibilidades, Sechi dá início ao projeto que seria, mais do que qualquer outro, o coração de sua ilha:

Em janeiro de 2003 nasce a Sechiisland's Micro Gallery. A "Micro Galeria da Ilha Sechi" é um espaço alternativo destinado a pequenas exposições individuais de artistas cujos trabalhos têm em comum o fato de estarem inseridos nos movimentos experimentais artísticos e literários surgidos a partir da década de sessenta do século vinte até os dias atuais.

A Sechiisland's Micro Gallery nasce com a pretensão de ser um espaço diferenciado dos tradicionais espaços para exposições:

$1 .^{\circ}$ - Recusa-se a ser posta no caminho das pessoas suplicando a atenção de algum ocasional transeunte interessado; ao contrário, exige que o visitante faça o primeiro esforço e desloque-se até a periferia da cidade para ver, ou melhor, "ler" uma exposição de artes plásticas ou poesia visual;

$2 .^{\circ}$ - Garante a cada pessoa interessada o mínimo de informações necessárias para a leitura de uma respectiva exposição;

$3 .^{\circ}$ - Acredita que o papel da arte é, sobretudo, informar e provocar nas pessoas a capacidade de questionamento. (SECHI, 2000, p.1).

Esse trecho concentra uma parte essencial do pensamento e posicionamento políticos do artista, bem como sua compreensão particular do significado da arte e sua importância social. Também fica claro, ainda que implicitamente, suas preferências estéticas e mesmo filosóficas ao definir que os artistas expostos seriam aqueles "cujos trabalhos têm em comum o fato de estarem inseridos nos movimentos experimentais artísticos e literários surgidos a partir da década de sessenta do século vinte até os dias atuais". Embora essa amostragem seja consideravelmente ampla, ela serve como um filtro para poupar Sechi de embaraços em relação aos meios artísticos tradicionais e conservadores aos quais ainda mantinha contato no meio social da cidade de Rio Claro. Membro honorário de uma associação de artistas plásticos da cidade - uma posição garantida, a despeito do próprio artista, pelo seu currículo de premiações - Sechi receava que a Sechiisland fosse vista como mais um espaço para exposições de naturezas-mortas e reproduções de retratos e paisagens que, além de artisticamente pobres, eram mais pretextos para eventos sociais e políticos do que reflexos de um interesse real por manifestações artísticas. O manifesto deixava clara a intenção de Sechi de, por um lado, separar a Sechiisland do limitado universo artístico oficial da cidade e, por outro, criar um espaço que aproximasse e concatenasse um outro universo artístico, por natureza mais subterrâneo e carente de visibilidade. Em suma, do alto do farol da sua ilha, Sechi sinalizava para "os seus".

E é nesse ponto que a Sechiisland torna-se mais do que a residência do artista, adquirindo uma existência independente como obra de arte em si mesma. Conceitualmente, a Ilha Sechi já era uma imagem poética perante todas as pessoas que relacionavam-se com ela via Arte Postal, mas com a inauguração da galeria, em $1^{\circ}$. de janeiro de 2003, ganha uma dimensão concreta, como uma instalação permanente que, no limite, pertence a todos que a procuram e se envolvem com ela e, desde o início, essa era a principal intenção do artista, o ponto de mutação de seu trabalho: a construção de um cotidiano diferenciado que englobasse o macrocosmo conceitual da mail-art e o microcosmo concreto das pessoas e eventos que a Sechiisland passaria a abrigar. Cada vez mais a morada desse "infame" tornava-se ponto de encontro de outros "infames", ampliando o círculo social que crescia em torno da figura, antes anônima, de Sechi, e contribuindo para sua evolução enquanto artista.

Em março de 2003 é criada a Sechiisland International Library, uma biblioteca especializada em arte e publicações alternativas. Diariamente são recebidos 
livros, revistas, catálogos, zines, publicações experimentais, livros de artista, vídeos, CDs, CDROMs, textos e outra informações.

Em novembro de 2003 é criada a pseudo-editora Edições 100 (sem apoio cultural, sem revisão ortográfica, sem pretensões literárias, sem valor comercial), cujo logotipo passou a aparecer nas revistas Pense Aqui e em outras publicações alternativas. (SECHI, 2000, p.1).

Imagem poética, instituição alternativa, ilha imaginária, espaço para exposições e eventos, biblioteca de referência e editora. O conjunto de nomenclaturas - que, indubitavelmente, aplicamse à Sechiisland - evocam um gigantismo desconcertante. Tal imensidão existe, embora, paradoxalmente, surja da pequenez. A editora é caseira e os livros são editados em xerox numa tiragem de poucas dezenas; as exposições ocupam o espaço de um cômodo e cabem numa pasta quando arquivadas; os eventos poderiam ser chamados de reuniões de amigos, boemia, mas não raramente incluem a apresentação de performances, criação de poemas e, acima de tudo, um ato de vivência artística que amplia consideravelmente o panorama das artes do município de Rio Claro; a biblioteca, entretanto, a muito abandonou o aspecto caseiro para abarcar de fato a imensidão de seu potencial: diariamente chegam livros teóricos em várias línguas, catálogos, livros de artistas, cds, dvds, periódicos, sem contar o permanente fluxo de obras para a Pense Aqui, todas devidamente arquivadas e disponíveis para consulta. Mas é como "imagem poética" que o tamanho da Sechiisland extrapola uma avaliação simples e convida a um aprofundamento amplo e revelador.

\section{Visitando a Sechiisland: uma breve leitura cômodo a cômodo}

Os artistas interessados em ter seus trabalhos publicados na Pense Aqui, ou possuam material para ser doado à Sechiisland International Library, ou ainda queiram agendar uma visita à uma das exposições da Sechiisland's Micro Gallery, podem entrar em contato com o curador José Roberto Sechi através do endereço: Av. M29, número 2183, Jd. São João, Rio Claro-SP, CEP. 13505-410 ou pelo e-mail: sechiisland@yahoo.com.br (SECHI, 2000,p.1)

Assim se concluí e o manifesto de apresentação da Sechiisland que vínhamos lendo desde o início do capítulo anterior. Armados de seu convite, nos aproximamos do endereço, localizado num dos bairros mais carentes de Rio Claro, caracterizado por uma população de baixa escolaridade e atormentado por todos os tipos de mazelas sociais típicas das periferias. A Avenida M-29 é uma descida íngreme que termina num vale cortado por um córrego, além do qual se encontram os próprios limites da cidade. A pouco mais de uma quadra do vale, deparamonos com um sobrado indiferenciado das demais habitações. Diante do portão da garagem, chamamos o nome do artista que, prontamente, surge na única janela no alto, através da qual é possível ver as estantes repletas de livros e, dependendo do ângulo e da distância, objetos variados pendurados nas paredes. Embora limitada, essa primeira observação permite entrever um nível cultural contrastante com as condições precárias do entorno.

Após uma breve espera, o portão é aberto e somos recebidos por um homem de cerca de quarenta anos, desleixadamente vestido, magro, de estrutura diminuta e ar tímido, que nos convida a acompanhalo, através de uma insuspeita garagem, até um estreito corredor que leva às dependências internas da propriedade, onde se encontram as habitações da mãe, da irmã e do sobrinho do artista. Mas nosso destino, entretanto, a despeito de uma possível curiosidade a respeito desse aspecto familiar (ao qual retornaremos mais tarde), é uma porta logo no início do corredor que conduz ao interior do sobrado. Aqui, num cômodo cuja função original era servir de ante-sala, encontraremos a Sechiisland' Micro Gallery em pleno funcionamento. 


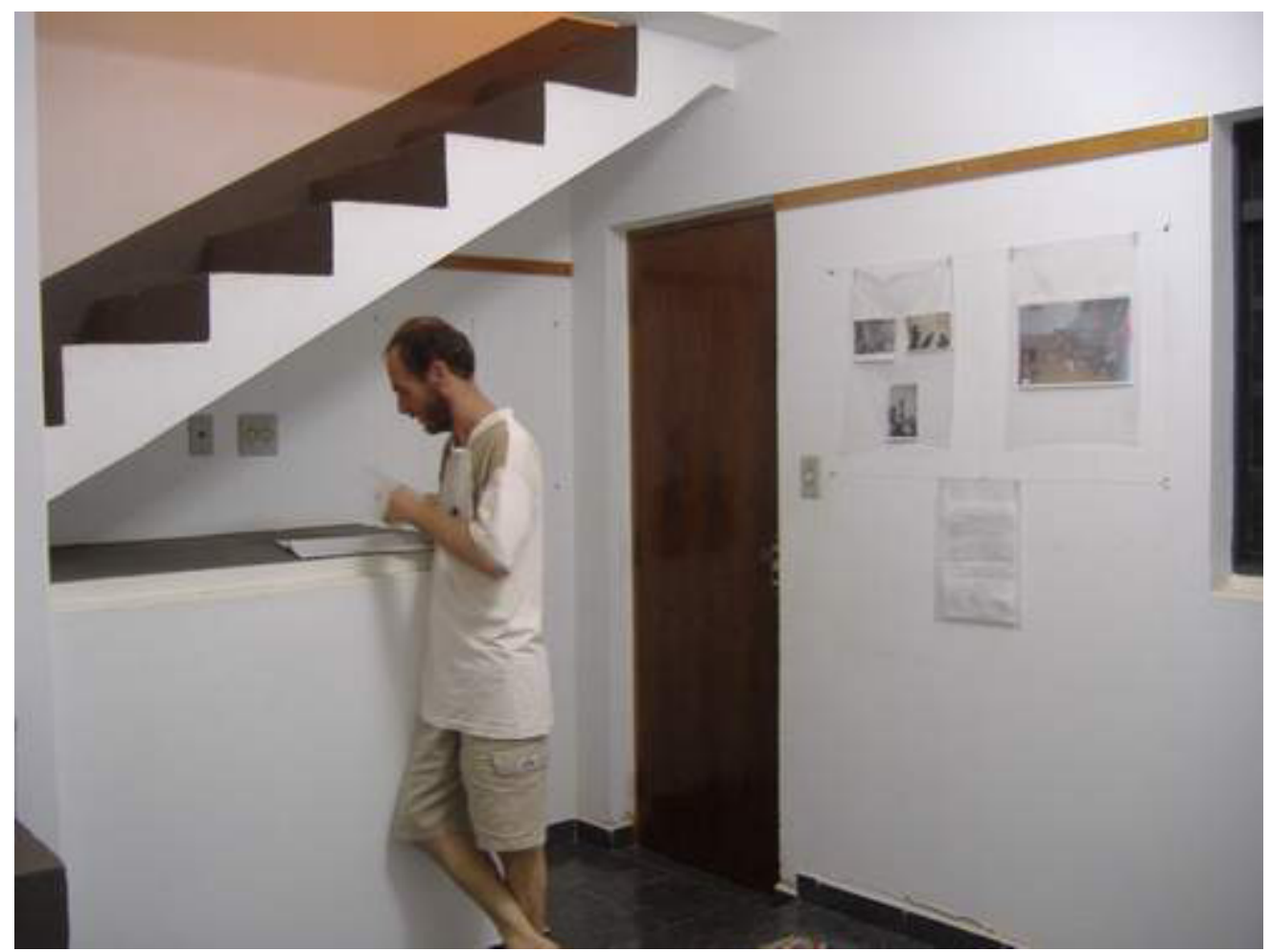

Figura 6. Entrada da Sechiisland's Micro Gallery, com Sechi folheando o Livro de Visitas.

O espaço tem cerca de quatro metros quadrados, paredes brancas e limpas. Há uma única janela, com vista para o corredor. Uma segunda porta, fechada, no canto oposto. Uma escadaria em L cujo ponto superior fica exatamente sobre a porta pela qual entramos, diante da qual há um alpendre onde encontraremos um livro de visitas (Figura 6) com as assinaturas de todos os freqüentadores da Ilha Sechi. Uma folheada rápida no livro fornece alguns pormenores a respeito das exposições já realizadas ${ }^{4}$, com uma média de 25 assinaturas cada, porém contando com picos de até 40 visitantes em certas épocas. O livro é apenas o primeiro dos vários registros passíveis de consulta arquivados na Sechiisland.
As obras encontram-se penduradas nas paredes em embalagens plásticas preparadas e distribuídas de acordo com o número de trabalhos, características e possíveis instruções dos artistas. $\mathrm{Na}$ maioria das vezes, o que veríamos seria uma distribuição uniforme no espaço, preenchendo as paredes desde o canto ao lado do livro de visitas até o topo da escadaria, de modo que o visitante, para apreciar da primeira à última obra, seja naturalmente conduzido até o nível superior do sobrado (Figura 9). Durante todo o percurso, Sechi porta-se como curador, respondendo perguntas e fornecendo as informações necessárias para que o visitante tenha condições de ler a exposição.

4 Ver relação completa das exposições no anexo. 

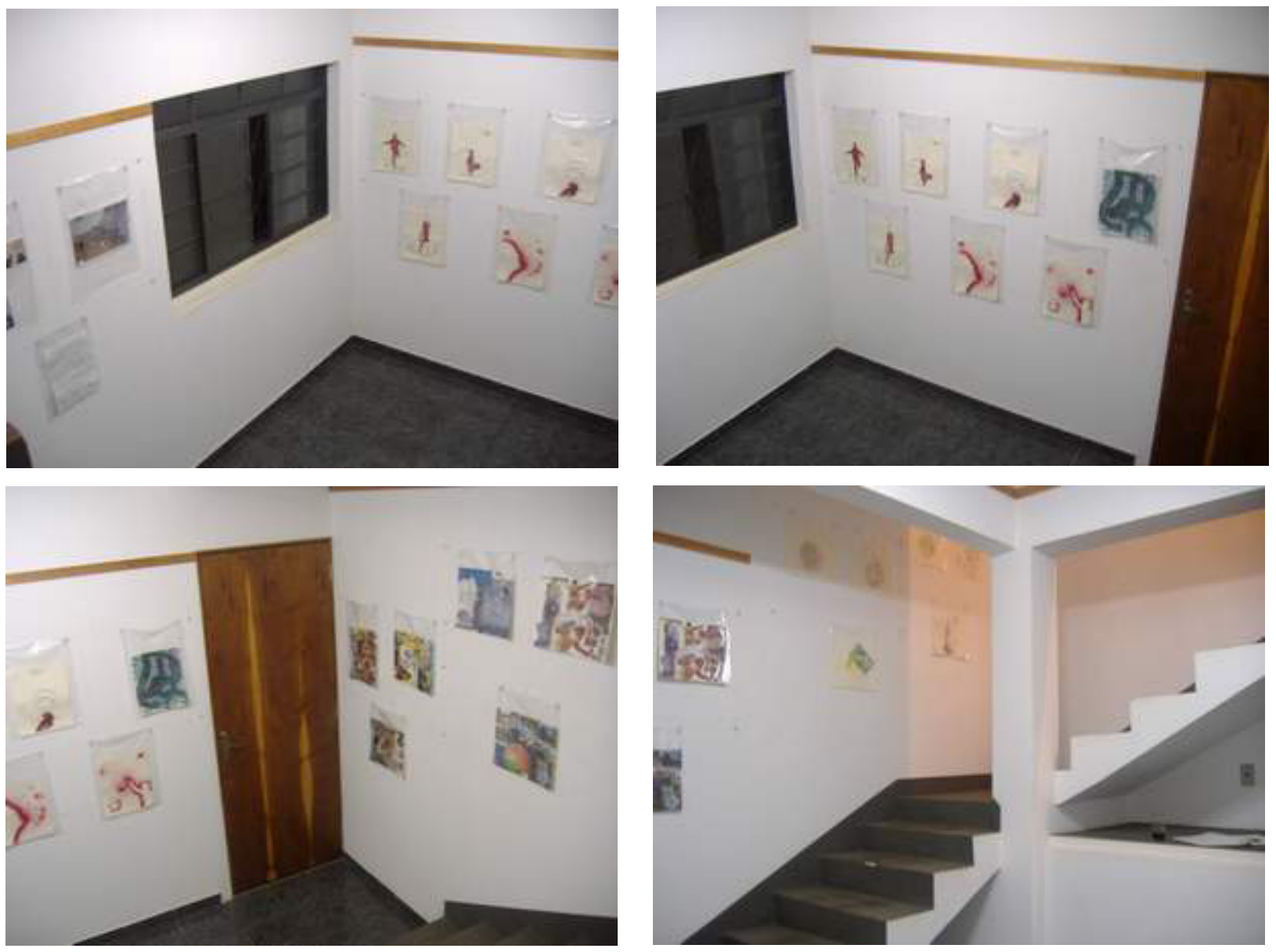

Figura 9. Visão geral do espaço para exposições.

Entretanto, no momento não é nas exposições mas na Sechiisland em si que voltamos nossa atenção, e corremos os riscos de nos esquivarmos um pouco da objetividade ao apontar impressões que, apesar de compartilhadas por muitos visitantes, não deixam de ser pessoais, no entanto, é inegável que o primeiro impacto que se faz sentir, numa visita inicial, é o desconcerto pelo aparente absurdo da situação. Estamos diante de um homem que, com grave seriedade (ainda que sem faltar com a ironia), disserta com familiaridade a respeito do universo artístico underground e mantém, em sua residência, uma galeria de obras experimentais que, embora caseira, denota um considerável esforço de organização e disponibilidade, sem ter por trás de si, "autenticando" e/ou "validando" seu trabalho, nenhuma instituição, órgão ou financiamento comumente associados às manifestações culturais.
Além disso, este homem nos apresenta a dita Sechiisland como uma instituição representativa o suficiente para garantir a manutenção das exposições. Para os não-familiarizados com o modo atrevido e espirituoso com que a rede de Arte Postal apropriase, sem cerimônias, de quaisquer símbolos, valores e procedimentos da cultura capitalista ocidental cristã (e qualquer outro conjunto cultural oficialmente estabelecido, na verdade) todo o trabalho despendido na Sechiisland parece despropositado, mesmo absurdo, uma vez que, para todos os efeitos, não tem nenhum valor de representação oficial. Leva tempo e, naturalmente, uma boa dose de boa vontade, para que o visitante comece a compreender que é justamente o significado prático de qualquer tipo de oficialização que está sendo questionado aqui. Esse sentimento de perplexidade nos acompanhará durante toda a visita. 
Num primeiro momento, deixar-nos-emos conduzir pelo fluxo planejado para a exposição e subiremos as escadas em direção às demais dependências da Sechiisland, aparentando não notar que uma porta permaneceu fechada lá embaixo, sem sequer ser mencionada pelo artista. $\mathrm{O}$ visitante habitual, de fato, tende a desconsiderar essa porta, julgando se tratar de um cômodo comum como o de qualquer residência, uma cozinha, uma área de serviço, algo fora dos limites dessa imagem poética tão bem cuidada, algo que pertence ao reino do privado. $\mathrm{Na}$ verdade, as fronteiras entre a vida privada e a vida social são bastante tênues nesse cotidiano erigido, e se é fato, como nos atesta Bachelard (1993), que uma casa é mais do que o reflexo de seu habitante, mas sim o próprio, quão singularmente complexa e reveladora seria essa casa de origens tão diferenciadas? O que nos teria a dizer seus recantos secretos, aqueles que, mesmo numa casa comum, são tão reveladores. Porém, ao menos por agora, o desejo de empreender essa visita e essa leitura de acordo com os caminhos de qualquer visitante que adentre a Sechiisland pela primeira vez nos leva a adiar o desvendamento desse recanto secreto. Seu momento irá se apresentar.

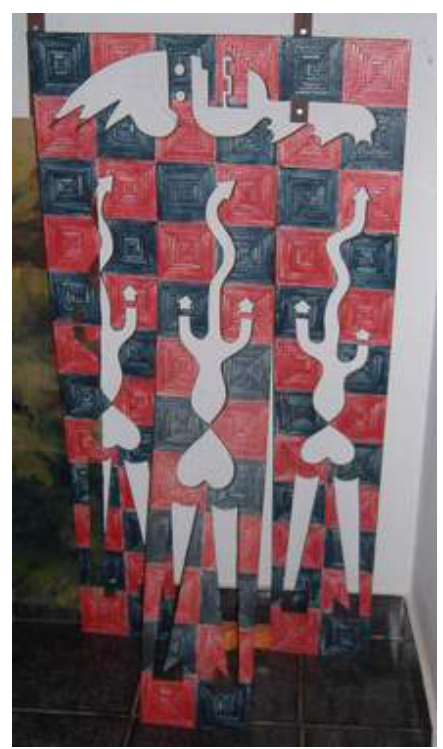

Figura 10. Série Antifiguras - Ritual de Acasalamento / Buscadores de Máscaras.

As escadas nos conduzem até um estreito hall, onde temos o primeiro contato com as antigas obras plásticas de Sechi na forma de duas esculturas em madeira pertencentes a série Antifiguras: Ritual de Acasalamento (Figura 10A) e Buscadores de Máscaras (Figura 10B), ambas de 1998. Nelas já é possível observar a característica aparência totêmica das figuras imaginadas pelo artista. Sechi explica que o termo Antifiguras provém do fato das imagens presentes nas esculturas estarem relacionadas não à presença mas sim à ausência de material esculpido.

Sobre as esculturas encontra-se o Altar de Todos os Deuses (Figura 11), uma coleção desconjuntada de objetos afins, amontoados sobre uma prateleira ou afixados em um tecido estendido na parede. Miniaturas de orixás, pequenos trabalhos de artesanato, buttons de vários tipos, brincos, colares, um teclado de computador, um ursinho de pelúcia, um modess ainda lacrado, um crânio de gato, um ícone da igreja católica ortodoxa russa, uma garrafa de água mineral, uma lata de pepsi, uma touca do exército soviético, uma boina africana e muitos outros objetos que têm em comum apenas o fato de serem presentes enviados pelo correio ou deixados pelos visitantes no decorrer desses quatro anos de existência da Sechiisland. 


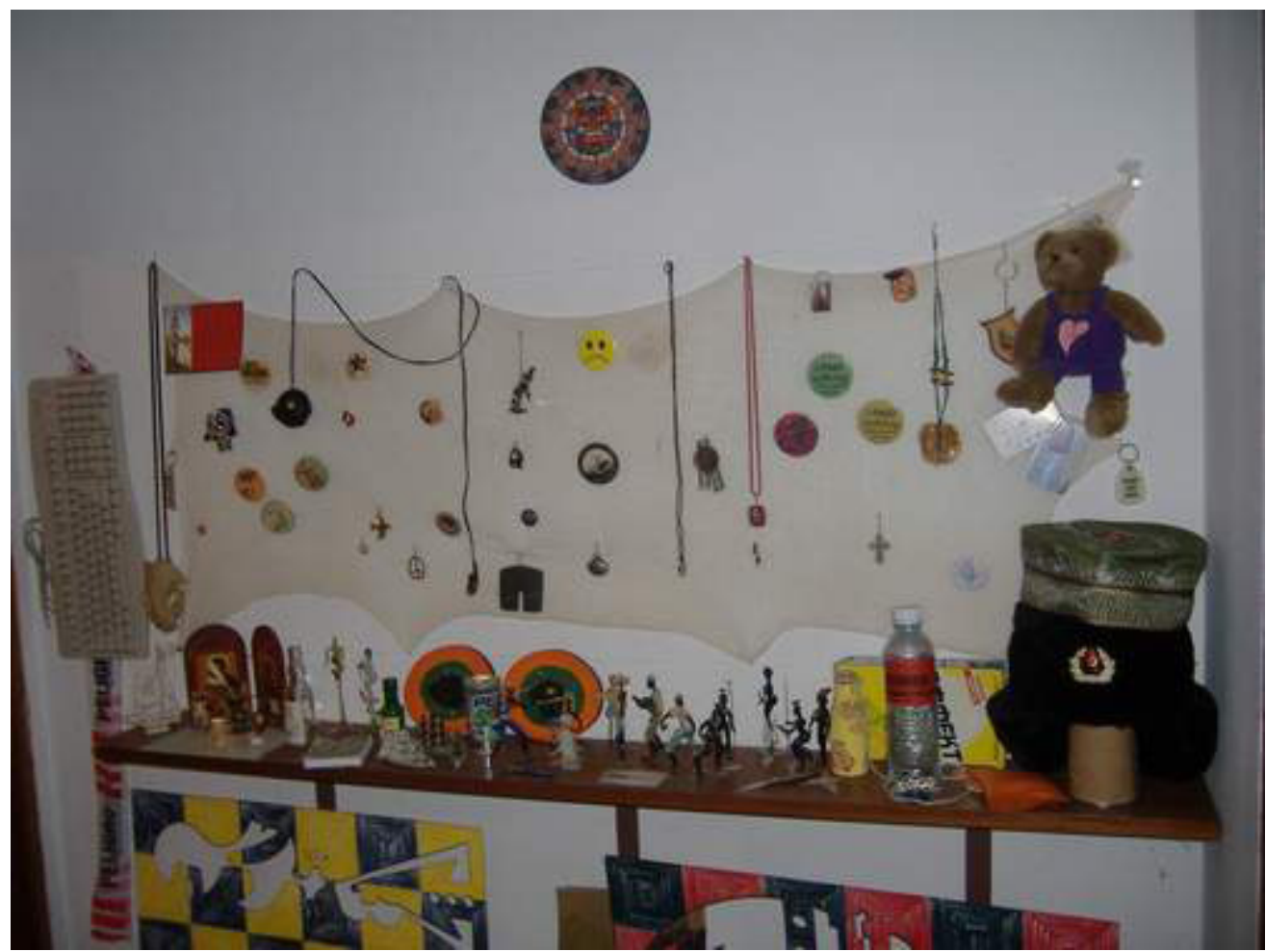

Figura 11. O Altar de Todos os Deuses.

Embora tratado jocosamente pelo artista, o altar é bastante significativo quando considerado numa perspectiva histórica, uma vez que sua existência só foi possível graças às visitações e aos contatos postais. Nos primeiros tempos, pouco depois da inauguração da microgaleria, esse mesmo espaço era ocupado por pinturas em tecido autoreferenciais, nas quais a imagem fotográfica do artista (criança, adolescente e adulto) aparecia mesclada com seringas e agulhas de aplicação de insulina, bem como às agressivas figuras totêmicas, evocando sentimentos de solidão, desenraizamento e inadequação. $O$ fato de esses trabalhos terem sido substituídos pelo colorido "altar" parece denotar uma transformação nas possibilidades de leitura da Sechiisland e, claro, na própria psique do artista. Um dos objetivos principais da ilha imaginária mais ou menos ali se realizava e um espaço exclusivamente privado e solitário tornava-se, em muitos aspectos, público e rico em vida social.

A visita continua e adentramos o verdadeiro coração da Sechiisland, um cômodo que poderíamos muito bem chamar de Farol (Figura 12), tanto por suas características físicas quanto "conceituais". O ambiente é dominado por uma grande mesa de madeira compensada, permanentemente atulhada de papéis, tintas, canetas, lápis, tesouras, colas, recortes, revistas e todo e qualquer material passível de ser utilizado na criação de trabalhos de Arte Postal e na convecção da revista Pense Aqui. A própria tampa da mesa, coberta de manchas afins, começa a assemelhar-se a uma tela em andamento e não foram poucas as colaborações, intencionais ou não, dos visitantes reunidos ao redor da mesa com os ânimos exaltados e os copos cheios de vinho "seco e amargo como a vida" (em respeito à diabete do anfitrião). De fato, embora normalmente a galeria seja visitada por grupos pequenos, é nas inaugurações de cada exposição que o livro de visitas ganha a maior parte de suas assinaturas, as já célebres reuniões na Sechiisland, quando verdadeiras festas acontecem. Alguns freqüentadores são assíduos, mas o Farol já recebeu um universo bastante plural de indivíduos das mais variadas idades, tendências, 
pontos de vista e envolvimentos com arte (Figuras 13). No limite, é bastante imprevisível, mesmo para Sechi, a gama de pessoas que, por um motivo ou outro, acabam chegando à Sechiisland. Alguns aparecem convidados pelo artista, outros são trazidos pelos visitantes, outros ainda procuram o lugar por iniciativa própria, pelas mais variadas razões. Alguns aprofundam-se no universo artístico invocado pelo lugar, mergulhando nas surpresas da rede internacional de Arte Postal, outros apenas aproveitam o ambiente propício para a embriaguez e abrigo contra as mesmices cotidianas, mas todos, cada um à sua maneira, apropriam-se da imagem poética da Sechiisland como de fato deve ser com qualquer obra de arte.

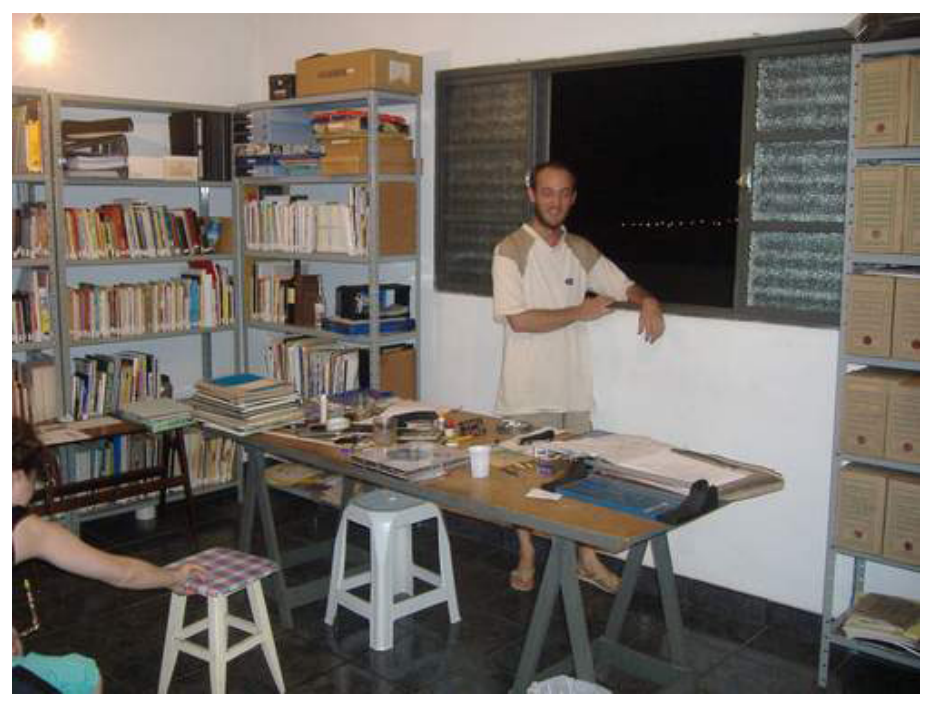

Figura 12. O Farol, cômodo principal da Sechiisland.
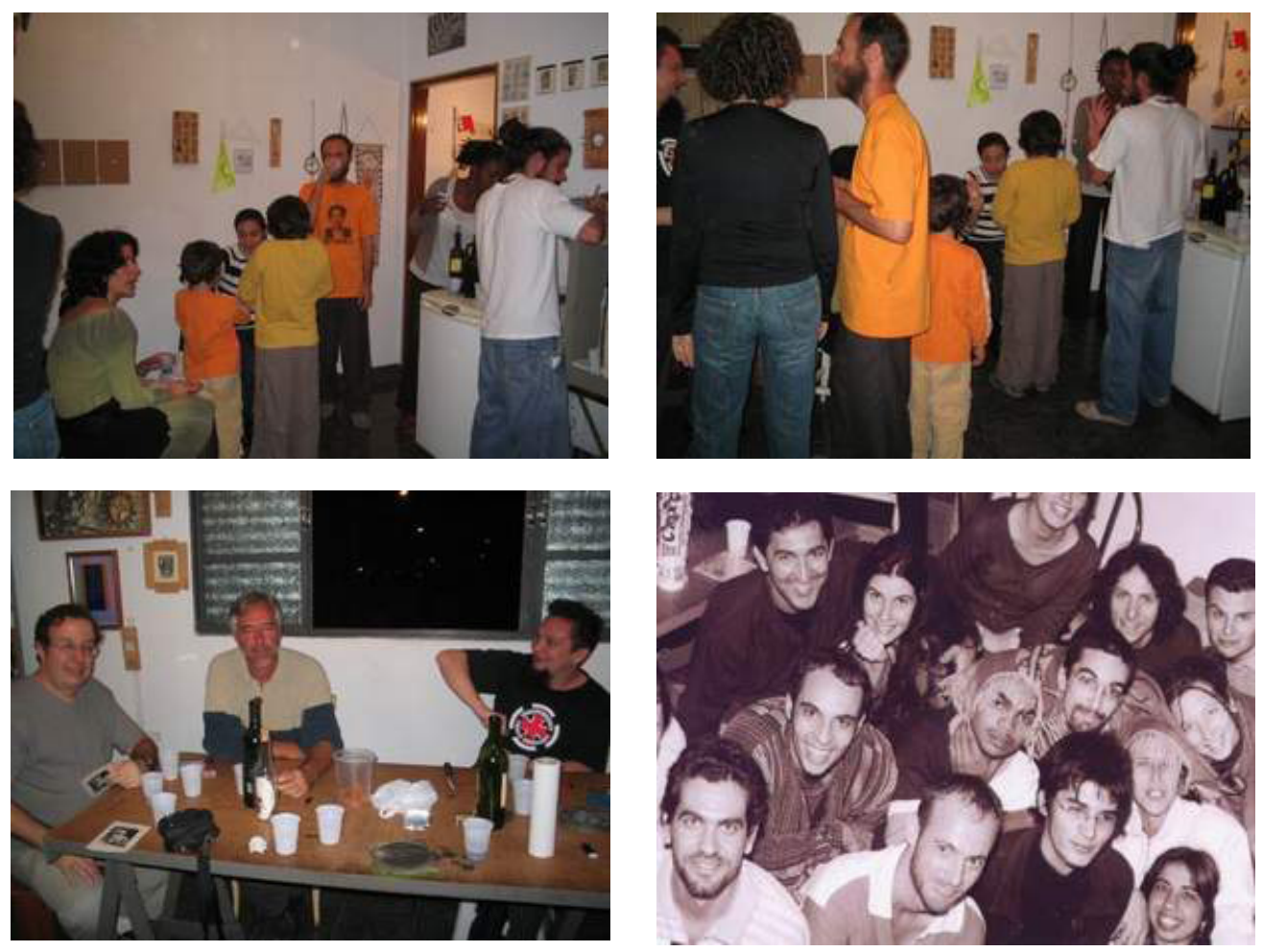

Figura 13. Diversas inaugurações de exposições, com o heterogêneo conjunto de visitantes. 
As paredes do Farol são enfeitadas com inúmeros objetos, como esculturas em madeira repletas de agulhas, exibindo o carimbo Made in Sechiisland, provenientes do período em que a ilha era, de fato, um lugar de isolamento (Figura 14A). Também são visíveis colares, alguns trabalhos de amigos de Sechi, como a artista plástica Letícia Tonon (velha companheira da militância arte-correista) e o escultor rio-clarense Eraldo Carlos Lacerda, autor de um quadro representando o próprio Sechi (Figura 14A), que se destaca entre o emaranhado de trabalhos e pode ser visto através da janela que dá para a rua. Essa janela (Figura 14B), é interessante notar, torna-se o único elo de ligação com o, tão contrastante, ambiente do bairro Jardim São João. Por meio dela, é possível ter uma visão ampla da

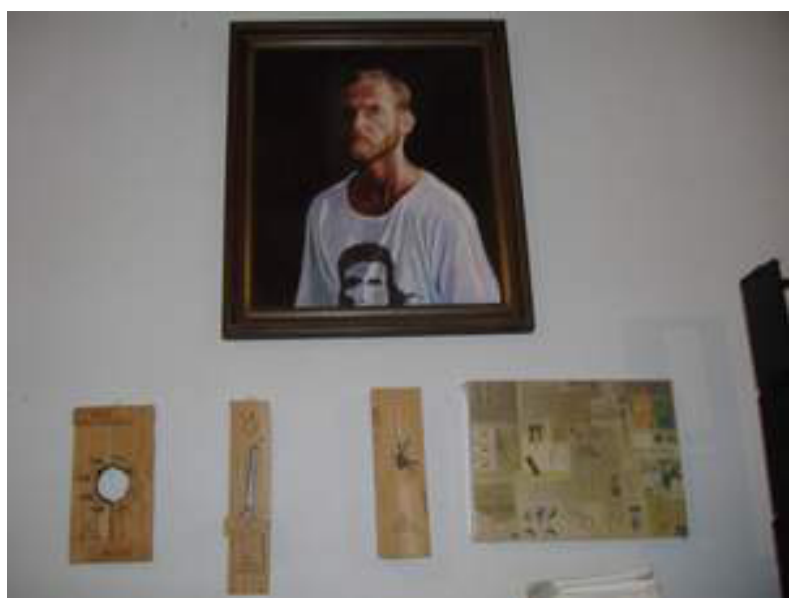

região, tão próxima e tão distante do micro-cosmo contido no interior daquelas paredes. Sua posição elevada e o efeito provocado pela luz no asfalto lá fora, reforça significativamente a característica de "farol" que a janela ganha, ainda mais ao considerar a função concreta de um farol: fornecer um ponto de referência e um porto seguro aos navegantes que atravessam a escuridão. Essa função perfeitamente com a terceira pretensão expressa no manifesto da Sechiisland, referente não só à galeria, mas ao papel social da arte em seu sentido mais amplo:

Acredita que o papel da arte é, sobretudo, informar e provocarnas pessoas a capacidade de questionamento (SECHI, 2000, p.1).

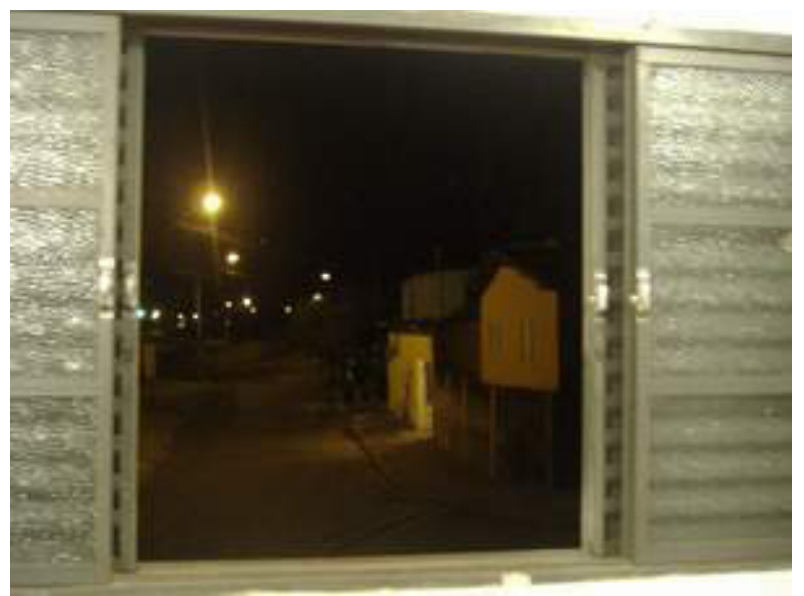

Figura 14. Retrato do artista e visão do bairro Jardim São João através da janela do Farol.

No canto ao lado da janela, à direita de quem entra, encontram-se duas estantes repletas de caixas de arquivo (como as que se encontram em despachantes e repartições públicas). Nelas estão arquivados todos os originais de obras de Arte Postal recebidos pela Sechiisland (Figura 15). Numa estimativa aproximada, cerca de 5353 trabalhos individuais, se levarmos em consideração apenas aqueles que foram reproduzidos na Pense Aqui até julho de 2006. Entretanto, dadas as limitações de formato da revista, que exigem que Sechi publique apenas um máximo de dois ou três trabalhos de um mesmo artista recebidos numa única entrega, deixando os demais (não importando a quantidade que, no caso de selos de artista, cartões e similares, pode ser extraordinariamente grande) unicamente para o arquivo, o número de trabalhos unitários pode ser até três vezes maior. 


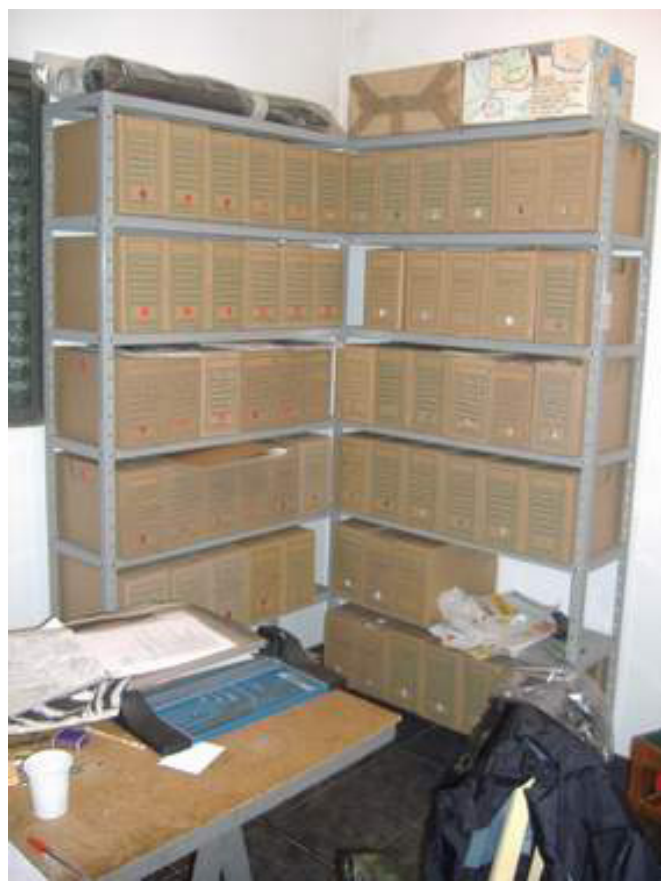

Figura 15. Arquivo de obras de Arte Postal.

As obras estão arquivadas segundo a data de chegada, organizadas em caixas classificadas por mês e ano, com algumas caixas específicas relativas a projetos de Arte Postal promovidos pelo próprio Sechi, como foi o caso dos projetos: $O$ Toque $e$ $o$ Traço (resultado da primeira oficina de Arte Postal realizada em Rio Claro envolvendo poetas e artistas plásticos) de 1999; Onde Você Mora? (com 70 participantes de 23 países), Só Objetos de Uso Pessoal (com 355 participantes de 43 países), ambos de 2000; Equilíbrio Ecológico - com a colega Letícia Tonon - (119 participantes de 31 países), em 2001; O Amor - também em co-autoria com Letícia Tonon - (208 participantes de 43 países), 2002 e, finalmente, Borboletas (com 113 participantes de 29 países) em 2005.

Fazem parte do arquivo três livros de registro, manuscritos, continuamente atualizados: $1^{\circ}$ : uma relação completa de todos os artistas presentes na rede de contatos de Sechi - organizados segundo o país de origem -, constando nome e/ou pseudônimo do artista e o número de obras enviadas por cada; $2^{\circ}$ : um registro do número de trabalhos reproduzidos na Pense Aqui, segundo o país de origem; $3^{\circ}$ : relação de projetos de Arte Postal que contam/contaram com a participação de Sechi, organizados em ordem cronológica, constando o país de origem e se a documentação referente ao encerramento do projeto (catálogos, anúncios de exposição, relação de participantes) foi recebida pelo artista.

Esses registros merecem uma atenção especial, por permitirem um vislumbre da imensidão, insuspeitada num primeiro momento, da rede de Arte Postal. O registro de contatos impressiona não apenas pelo número de interlocutores mas, em especial, pela amplitude territorial representada pelos países de origem. Embora a grande maioria dos artistas seja proveniente de países como Brasil, EUA, Canadá, Argentina e União Européia, marcam presença lugares tão díspares quanto Grécia, Nova Zelândia, Taiwan, Rússia, China, Japão, República do Mali, Sri Lanka, Vietnã, África do Sul, Moldova, Malaysia, Tanzânia, Burkina Faso, Líbia ou Nepal. A impressão inicial é de uma grande Torre de Babel, mas uma conversa rápido com o artista deixa claro que a comunicação, via Arte Postal, explora os limites mais extremos da linguagem, indo muito além de uma mera questão de idiomas. Ainda assim, 
no caso de um interlocutor naturalmente curioso e autodidata como Sechi, o próprio exercício da Arte Postal acaba levando ao aprendizado de diversas línguas, senão aprofundadamente, ao menos $\mathrm{o}$ suficiente para o diálogo escrito e imagético.

O real choque vem ao folhear as páginas do registro de projetos de Arte Postal, e aqui cabe uma pequena explicação de como tais projetos normalmente funcionam. O termo "projeto" insinua uma oficialidade e mesmo um aspecto institucional. A palavra, comumente relacionada ao mundo prático da ciência e da política, passa a impressão da existência de órgãos que, de um modo ou de outro, avaliam e/ou co-ordenam o aparente caos da rede. A pergunta que se imagina é quais órgãos, grupos, instituições ou mesmo artistas mais experientes e representativos deferem projetos de Arte Postal? A resposta é que simplesmente qualquer pessoa pode, a qualquer momento, propor um projeto, que será levado em consideração pelos demais artistas da rede tão (ou mais) seriamente quanto qualquer projeto institucional. O único limite será o interesse/ identificação de cada artista com o tema do projeto e seu desejo pessoal de participar. Assim, uma pequena idéia surgida em um lugar qualquer do mundo pode gerar um movimento do qual, no limite, ninguém terá controle ou capacidade de previsão.

Usando um projeto do próprio Sechi como exemplo, "Só Objetos de Uso Pessoal” propunha que os artistas enviassem objetos pessoais para a Sechiisland. A divulgação do projeto foi feita pelos vários contatos que Sechi mantinha na ocasião. Independente do número de convites enviado, é muito difícil prever até onde um projeto poderá chegar pois os mail-artistas repassam e multiplicam os convites. Numa entrevista concedida ao Jornal de Londrina, em 21 de Agosto de 2005, Sechi descreve algumas conseqüências do projeto:

(...) eu pedia para me mandarem trabalhos cujos temas fossem "objetos pessoais". Quando enviei o projeto para outros países usei uma palavra em inglês: "thing" (coisa). Aí começaram a aparecer coisas...
Um grupo de artistas alemães me mandou uma caixa cheia de unhas. Acho que tinha unhas de umas 50 pessoas. Um artista italiano fez uma performance em que fotografou o abdômen dele próprio até a parte dos pêlos pubianos, e depois a mesma parte do corpo depilada. Entre essas duas fotos, ele mandou um saquinho com os pêlos. A correspondência que eu julguei mais surpreendente e radical, até hoje, foi a de uma artista americana. Era um monte de papel enrolado. Fui desenrolando o papel e no final havia um tubo de ensaio e, dentro do tubo, um absorvente interno usado. (SECHI: Entrevista Jornal de Londrina 21/08/2005)

Essa amostragem (devidamente arquivada) dá uma idéia da variedade de manifestações artísticas que a rede produz. O resultado final do projeto foi uma exposição dos resíduos (que é como os trabalhos são considerados, visto que a Arte Postal se realiza no momento em que o objeto troca de mãos, via correio, e a comunicação acontece) mas poderia ter sido a criação de um catálogo, de um site ou, meramente, o envio dos dados do projeto para os participantes. No caso de "Objetos de Uso Pessoal", o projeto movimentou 355 participantes de 43 países, mas esses números podem até quadruplicar em alguns casos.

Toda essa tangente para esclarecer a dimensão revelada pelo registro de projetos nos quais Sechi participou: o livro de registro relaciona mais de 732 projetos, em andamento ou já concluídos, desde o início do envolvimento do artista com a rede em 2002.

São números impressionantes, sem dúvida, muito maiores do que se esperaria para um movimento artístico undergroud ao qual a mídia - com exceção de raras ocasiões - sequer tem conhecimento (ou interesse). Os próprios livros de arte conceitual e estudos acadêmicos costumam referir-se à Arte Postal como um movimento dos anos 50 e 60, parecendo ignorar sua representatividade hoje. Há notáveis exceções, evidente, como é o caso de Poéticas do Processo - arte Conceitual no Museu (FREIRE, 1999) e os artigos escritos pelos próprios mail-artistas e divulgados nas revistas alternativas 
como é o caso dos textos do artista uruguaio Clemente Padin, um dos mais atuantes e históricos representantes da rede de Arte Postal.

Mais preparados pelo que vimos e aprendemos até agora, a próxima etapa da visita acaba sendo mais facilmente digerível. Do outro lado do cômodo, temos cinco estantes abarrotadas representando a Sechiisland International Library (Figura 16), que já pode ser considerada uma importante biblioteca de referência artística. Desde sua divulgação, em março de 2003, a Sechiisland tem recebido um fluxo constante e quase diário de material de referência provindo de inúmeros países. Desde luxuosos catálogos ilustrados, até livros de artista manufaturados em edição única. Livros, zines, publicações experimentais, vídeos, CDs, CDROMs, DVDs, textos xerografados, mimeografados ou manuscritos, etc. Cada item adquirido é tombado pelo próprio Sechi, enquanto curador da Sechiisland, e classificado segundo um número de tombo, todos devidamente catalogados em outro livro de registro manuscrito no qual, até a data de redação desse artigo, constavam 3960 obras.

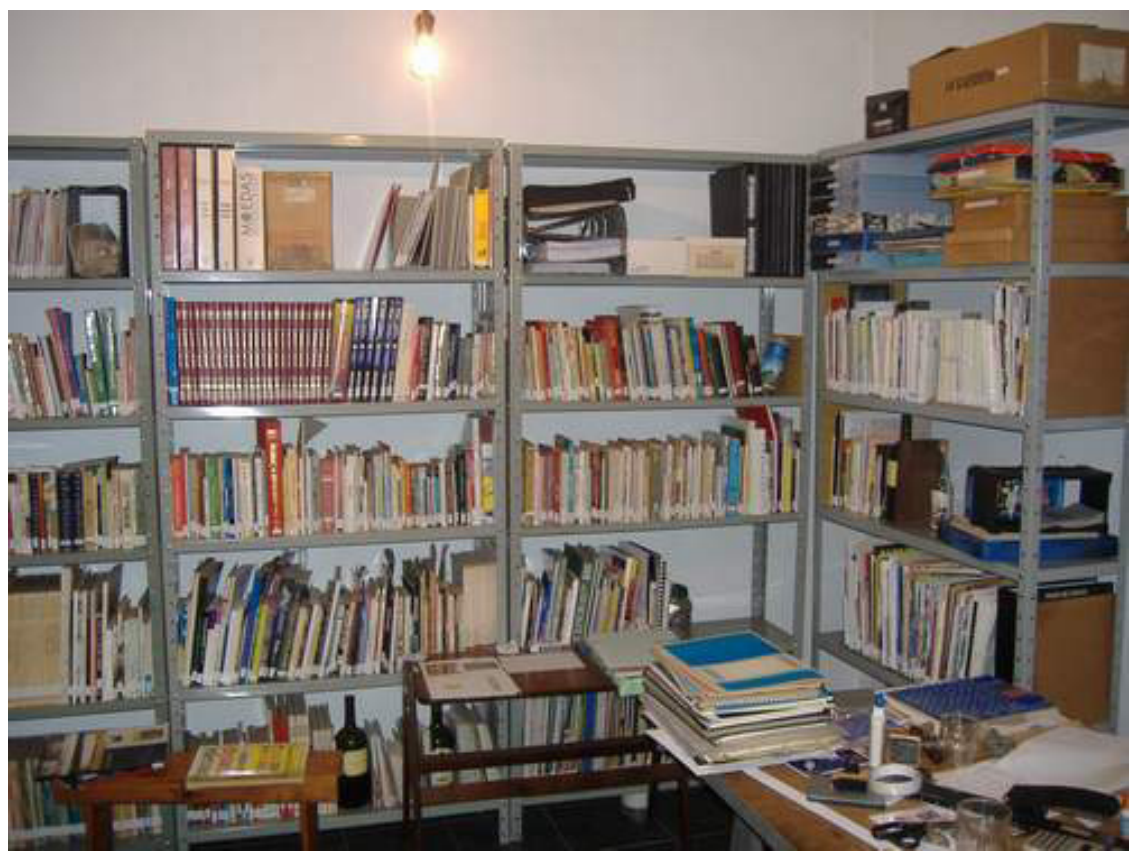

Figura 16. Acervo da Sechiisland International Library.

Enquanto nos sentamos para remoer tanta informação e apreciar uma copo de vinho seco, damo-nos conta da quantidade de trabalho envolvida em todo o processo. Desde que deixou o emprego nos Correios, Sechi dedica-se exclusivamente à "profissão" de artista, o que significa administrar a Sechiisland (cuidar da editoração da Pense Aqui, catalogar o material que chega para a biblioteca, manter o diálogo com seus interlocutores, participar dos projetos de Arte Postal, preparar as exposições e receber os ocasionais visitantes) e prosseguir com sua própria trajetória de artista plástico. Mesmo com todo o trabalho na sua ilha imaginária, Sechi continua participando de eventos, concursos e galerias, produz trabalhos cada vez mais experimentais, além de performances (Figura 17), happenings e praticamente quaisquer atividades artísticas que tem oportunidade de participar. 


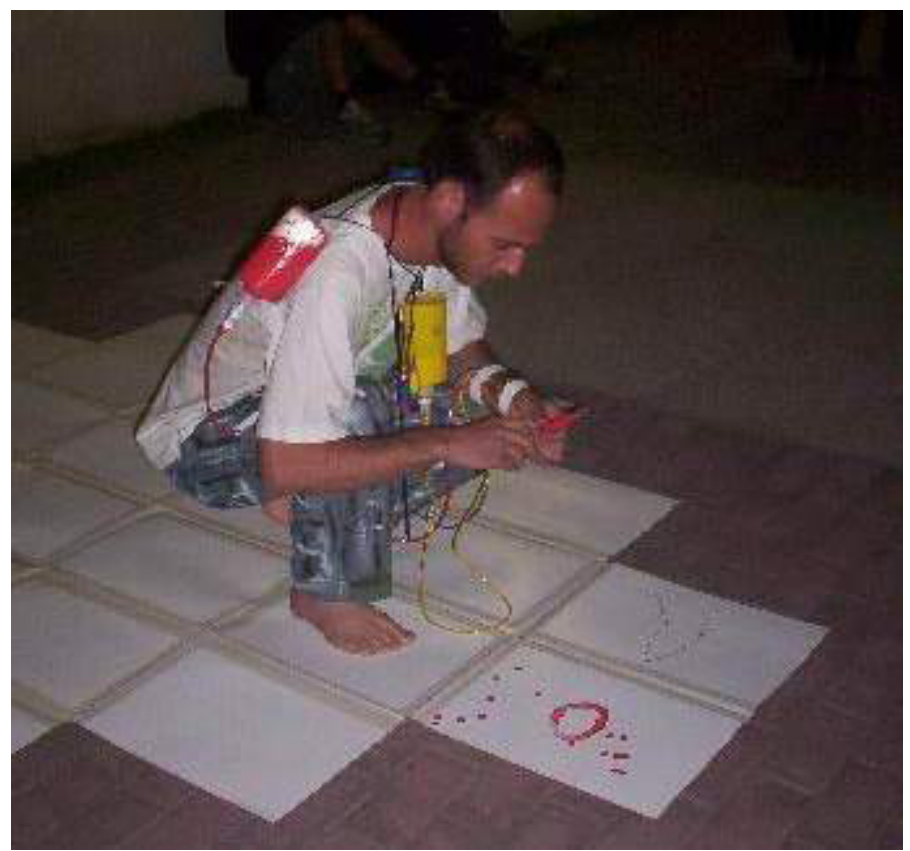

Figura 17. Sechi durante uma performance realizada na Argentina em 2005.

Obviamente todo esse trabalho tem custos. Só as despesas postais já são consideráveis. Até hoje, a Sechiisland foi mantida pelos encargos trabalhistas advindos da demissão dos Correios, uma fonte que se esgota rapidamente. A própria filosofia inerente à Arte Postal impede alguma forma de comercialização ou lucro e as possibilidades de ganho financeiro são bastante escassas, resumindo-se à ocasionais oficinas e convites para eventos. Atualmente, a Sechiisland busca possíveis financiamentos, agora que sua fase embrionária está, certamente, no fim. Porém, apesar da importância dessa questão financeira, o motor que sempre moveu o artista não passava perto disso. Caso contrário a Sechiisland jamais teria existido, afinal poucos empreendimentos poderiam ser mais desprovidos de sentido num contexto capitalista.

Ansiosos por ver mais, somos conduzidos de volta ao hall do Altar de Todos os Deuses, mas, dessa vez, seguimos para o outro lado, onde há mais duas portas, uma levando ao banheiro (onde, em meados de 2003, havia uma fotografia de presidente americano George W. Bush fixada no interior do vaso sanitário) e a outra ao quarto do artista. Há uma cama, um armário e diversas obras do período anterior à Sechiisland. Telas planas e tridimensionais, esculturas, onde temas como solidão, inadequação e angústia são presenças constantes (Figuras 18 e 19). No alto, um retrato de Lênin testemunha os tempos de marxista, figuras totêmicas remetem à horas em hospitais e a onipresença das agulhas. Tentamos imaginar qual era o cotidiano do artista que criou essas obras, o que ele sentia e almejava, o que ele tentava comunicar e, principalmente, o quanto ele difere do homem que hoje administra a Sechiisland. 

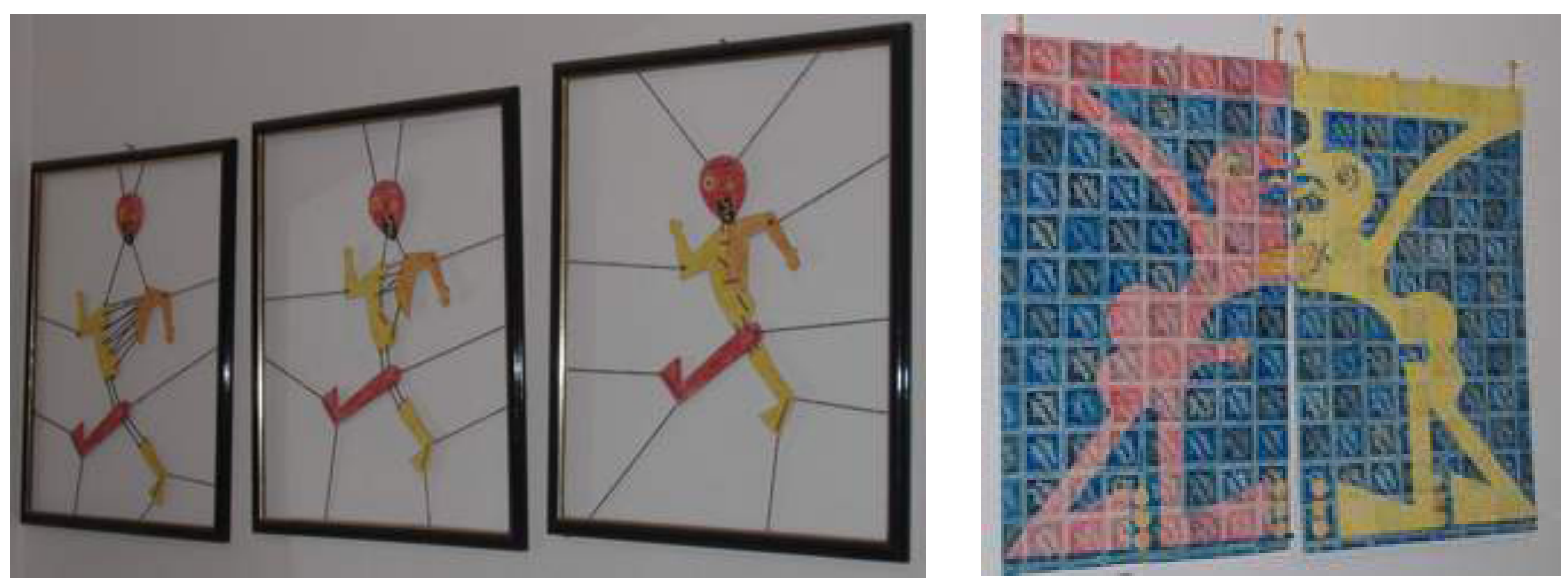

Figura 18. Algumas obras antigas presentes no quarto do artista: Um Passo em Hebron A, B e C (1995); Quase Um A e $B$ (1999).

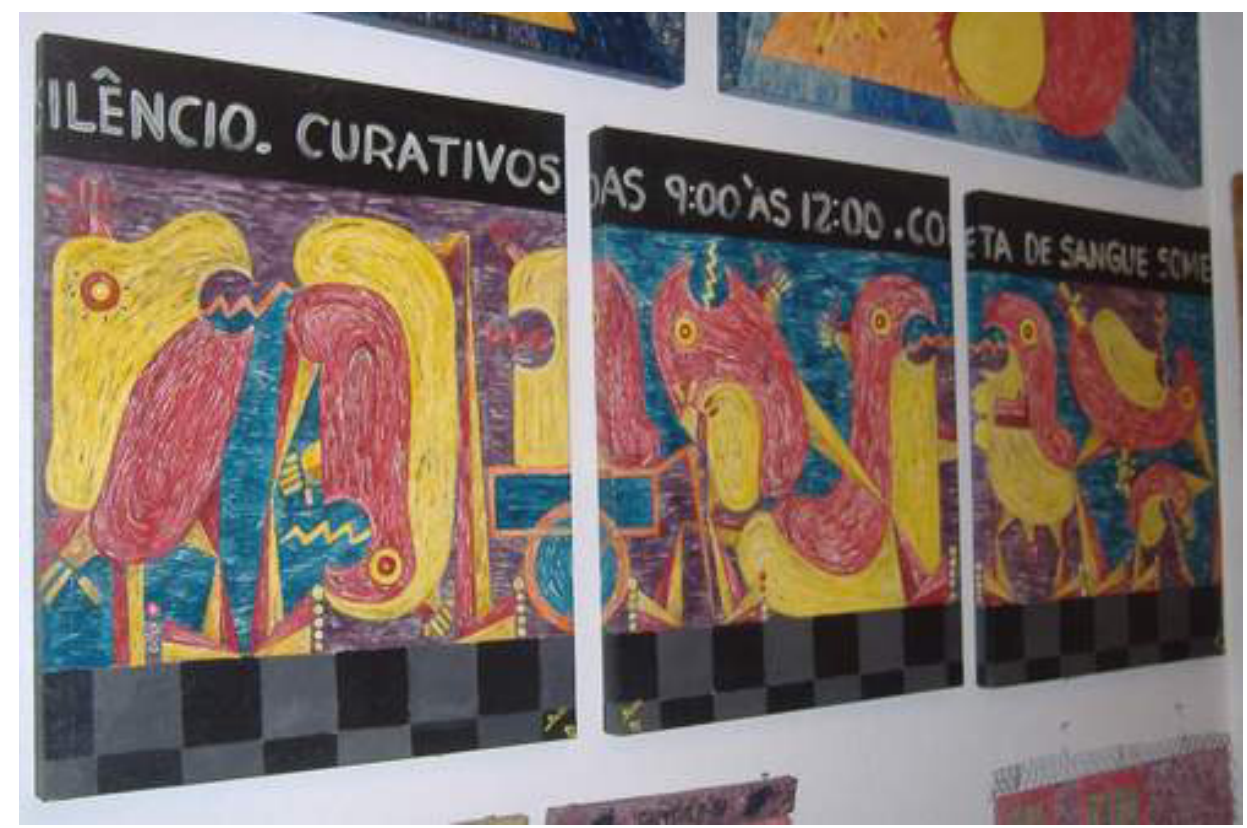

Figura 19. Mutilação Social-Previdência A, B e C (1992).

Curiosos a respeito desses trabalhos de uma era passada, pedimos a Sechi que nos mostre mais a respeito. Ele nos guia pelo caminho inverso, descendo as escadas, passando novamente pela galeria. Lá nos lembramos da porta fechada que chamou nossa atenção anteriormente e perguntamos dela. Desdenhosamente, o artista explica que trata-se de seu antigo ateliê, onde boa parte de sua primeiras obras foi feita, mas que não passa de um depósito de sucatas agora. Mesmo assim queremos ver, e o artista não se importa de destrancar para nós. A pequena sala contrasta bastante com a aparência bem cuidada - ainda que parcialmente caótica - do restante da casa. Mal é possível entrar, tão repleta que está de tranqueiras, ferramentas, e restos arruinados de velhos trabalhos. A sujeira e abandono sugerem que muito raramente alguém entra ali. Nos colocamos a imaginar quantas horas o artista teria passado nesse lugar, na época em que produzir sua arte estava intimamente relacionado com o isolamento e com o trabalho exaustivo, lento e metódico de recortar a madeira, moldar formas, preencher o vazio com 
pinceladas pequenas e intermináveis. Um processo de trabalho tão diferente da arte predominantemente conceitual que permeia todo o cotidiano erigido para a Sechiisland.

Deixando o ateliê para trás, Sechi nos leva para fora e para os fundos, onde moram a mãe, a irmã e o sobrinho. O ambiente seria perfeitamente corriqueiro não fossem as inúmeras obras do artista preenchendo todos os espaços nas paredes da sala de estar e do quarto da irmã. Algumas enormes, como as pinturas tridimensionais Escaramuças, O Preto e o Branco e Às Margens do Bosteiro, de 1994 (Figura 30). O conjunto das obras é impressionante. Os temas já observados nos trabalhos vistos anteriormente são explorados em variações obsessivamente coerentes (Figuras 20 e 21). As obras - a maioria divididas em séries de três - apesar de visivelmente mais passionais do que o trabalho atual do artista, já denotam sua tendência à experimentação das possibilidades da estética e da linguagem.

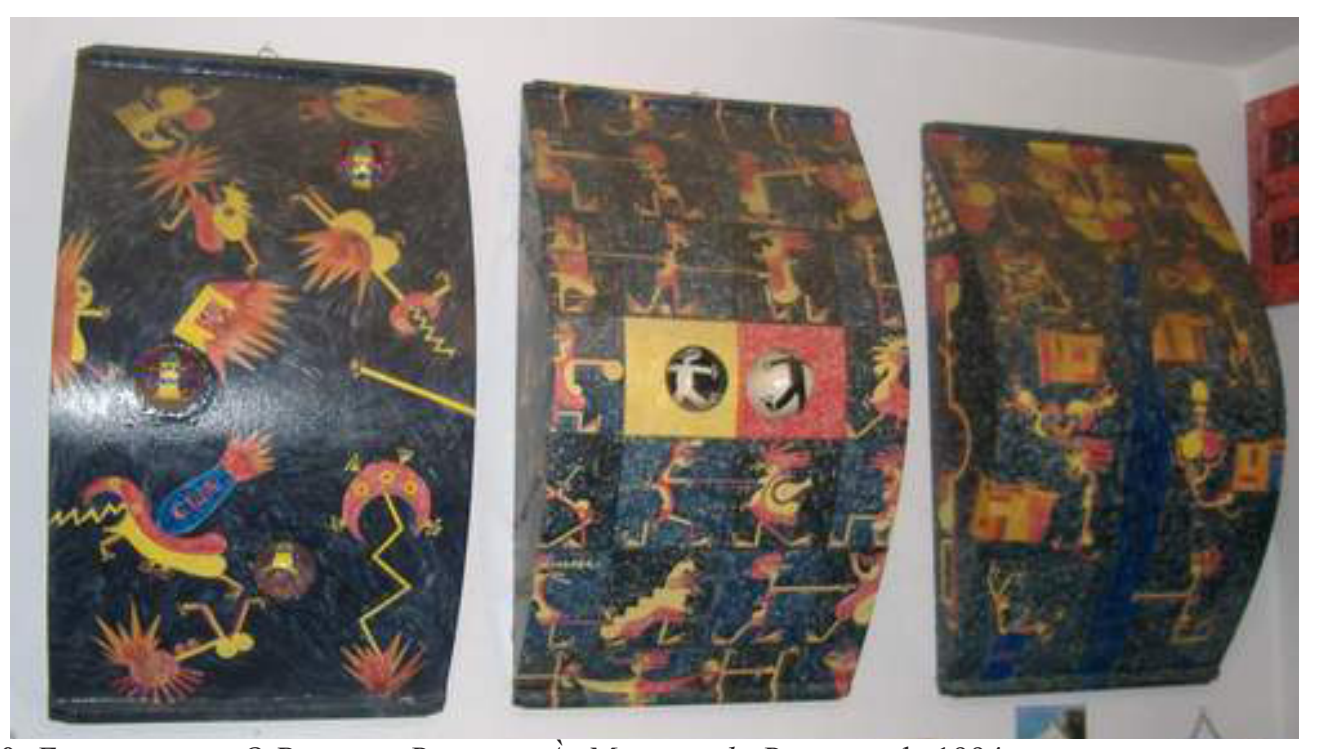

Figura 20. Escaramuças, O Preto e o Branco e Às Margens do Bosteiro, de 1994
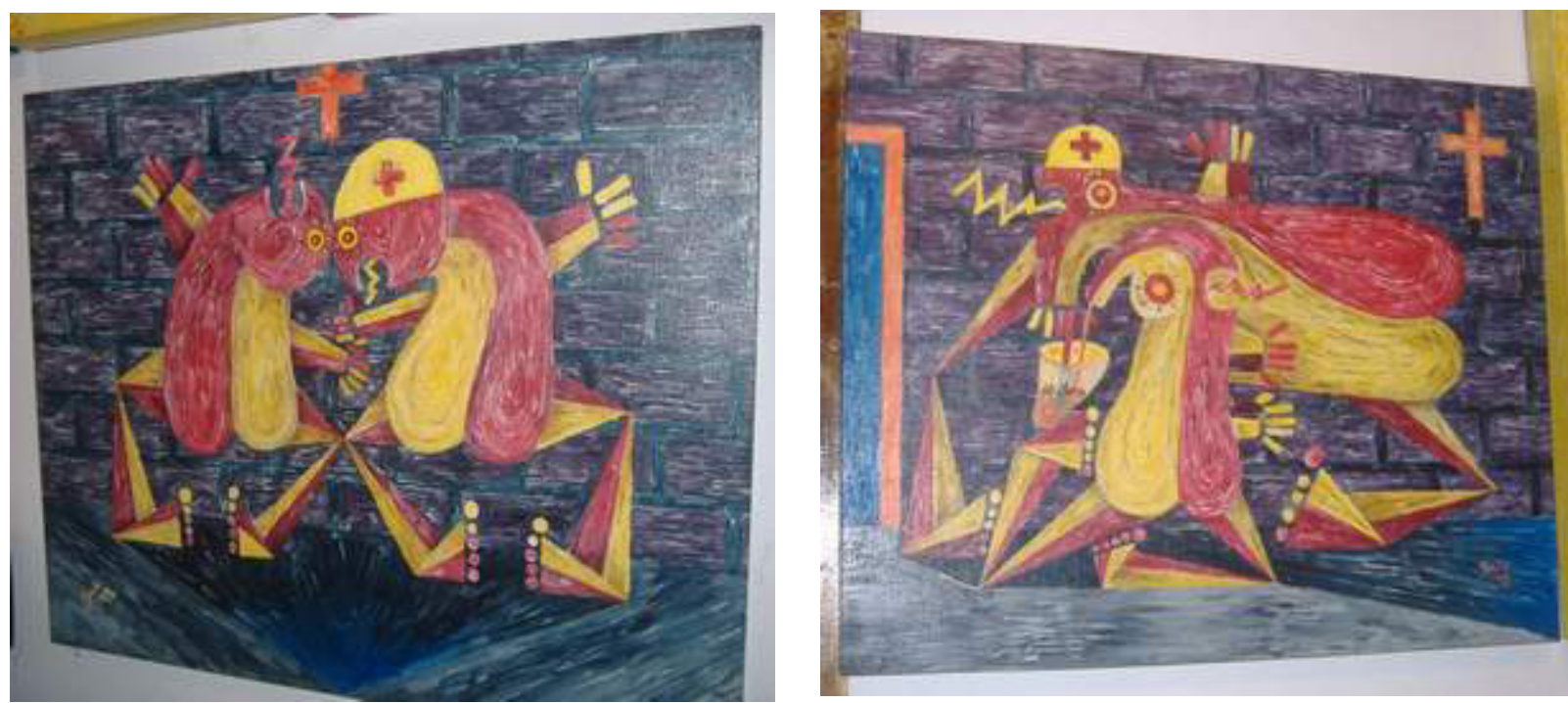

Figura 21. Exemplos de obras guardadas na sala de estar da família, Coleta de Sangue; Glicosuria, ambas de 1992. 
Enquanto, educadamente, aceitamos um café oferecido pela mãe, observamos aquele ambiente ao mesmo tempo familiar e exótico, onde objetos corriqueiros e cotidianos, idênticos aos de qualquer residência, misturam-se às imagens agressivas de uma arte singular. Conversamos brevemente com a irmã e constatamos similaridades bastante estreitas com o artista, reparamos nas tatuagens, no ar jovial de alguém que, embora obrigada a crescer muito rápido para sustentar um filho sozinha, ainda é jovem demais em muitos sentidos e parece, de fato, admirar o irmão e suas escolhas aparentemente ilógicas. Observamos a mãe, uma senhora evangélica degestos bruscos, cabelos longos eternamente presos numa trança comprida, ar e postura típicos das mulheres acostumadas ao trabalho braçal das lavouras, pouca instrução e inesgotável esperança nos caprichos de um Deus misterioso. Não é preciso perguntar para saber que os significados e implicações de toda a obra do filho lhe escapam completamente, mesmo convivendo com as imagens todos os dias. Sem dúvida, ela jamais compreenderia a dimensão da rede internacional que passa por sua morada, limitando-se a aceitar as "esquisitices" do filho como faria qualquer mãe. Segundo Sechi, nas ocasiões em que a mãe atende o telefone quando alguém procura informações a respeito da galeria, da biblioteca ou do arquivo de Arte Postal, a velha senhora costuma achar que trata-se de trote e não hesita em responder que a pessoa ligou para o número errado, afinal ali é apenas a casa de seu filho, onde ele gosta de guardar suas "bugigangas".

Ao retornarmos para a Sechiisland, ficamos imaginando o quão alienígena o jovem Sechi deveria sentir-se, o quanto sua necessidade de comunicação materializou-se nas suas obras e o quão frustrante fora a aceitação de que sua família, possivelmente, jamais seria capaz de compreender os sentimentos evocados pelas imagens, o canal de comunicação permanentemente embotado. Teria sido por isso que a rede de Arte Postal o atraiu tanto?

Mas não será na dissecação da psique do artista que compreenderemos melhor a dimensão da obra que o mesmo construiu. BACHELARD (1993, p. 5) afirmava que a imagem poética não tem passado e é preciso estar presente na imagem no momento da imagem, pois o artista não fornece explicações ou um passado para suas imagens, apenas as liberta no mundo, onde elas ganham vida própria e podem ser apropriadas por seus leitores tanto quanto o artista se apropriou do necessário para lhes dar vida. E, mesmo numa leitura tão preliminar da Sechiisland há muitas imagens com as quais podemos lidar.

\section{Considerações}

É sabido que muito da organização do espaço da Sechiisland foi determinado pelas condições físicas da residência de Sechi, entretanto é fascinante perceber que, apesar disso, uma lógica implícita se inseriu no ambiente. O quanto essa lógica é planejada ou consciente não importa, no momento, o que nos importa são as possíveis leituras. É bastante significativo verificar que a Sechiisland's Micro Gallery foi montada num cômodo intermediário, quase um vestíbulo, entre o exterior e os cômodos nos quais o artista de fato habita. Por sua própria estrutura, a galeria conduz o visitante a subir as escadas, seduzindo-o a não apenas passar por ela, mas sim deixar-se conduzir para a intimidade do artista. O hall que serve de ante-sala para o Farol, por mais jocosamente que seja tratado, insinua uma dialética sagrado/profano com seu espirituoso “Altar" e, como já foi mencionado, representa uma grande transformação em relação às auto-referentes e angustiantes imagens em tecido que recebiam os visitantes quando a Sechiisland começou. Aquelas eram imagens que pareciam pedir ao leitor compreensão e, se não tentavam ganhar sua piedade, ao menos não lhe permitiam esquecer a natureza da intimidade que adentrava. O "altar", que de certo modo silenciou aquelas imagens, é um convite à participação do leitor, um convite à interatividade, à colaboração numa obra em andamento, ao riso, à surpresa, ao conviver. De qualquer forma, tanto na imagem antiga quanto na nova, o hall é um 
espaço de pausa, é quase impossível simplesmente passar por ele. Ele convida à contemplação e uma preparação para a entrada na concha representada pelo Farol que, sob muitos aspectos, não faz parte do continuon espaço/tempo do mundo lá fora, ao menos não em sua dimensão mais corriqueira.

O Farol, em si, transmite a ambivalência da concha. Suas dimensões físicas pequenas contrastam com a imensidão da rede que ele representa e, de certa forma, abriga. É comum que o visitante alterne-se em sentimentos diametralmente opostos: ora sente-se protegido e seguro, desejando permanecer horas e horas inserido naquele pequeno cosmos de manifestações artísticas ao sabor do vinho e das conversas agradáveis; ora é tomado pela claustrofobia que nem mesmo a presença de um computador ligado à internet - pequena janela para o mundo que, ali, parece tão ilusória diante da força das imagens fisicamente presentes - consegue aliviar. Tudo depende do quão necessitado de abrigo o visitante esteja e o quanto se sinta ligado (ou não) ao mundo cotidiano. Essa alternância é o filtro que a Sechiisland naturalmente faz passar os visitantes.

Embora, no fim das contas, essa continue sendo a casa de uma pessoa, seu caráter cosmopolita facilita a integração e o próprio anfitrião as vezes assemelha-se a mais um visitante misturado entre as pessoas que se divertem nesse círculo de boêmios. Irônico, Sechi nem de longe tem a tendência de sacralizar seu trabalho e a condição de artista, preferindo o trocadilho e o comentário jocoso ao invés da seriedade dos discursos e nobres intenções. Tendo participado de doutrinas tão opostas quanto o cristianismo evangélico e o marxismo, Sechi tem todos os motivos possíveis para rejeitar qualquer forma de radicalismo e adotar como filosofia de vida os pressupostos quase anarquistas da Arte Postal. De seu ponto de vista, todos os visitantes ali presentes são artistas, pois o artista é aquele que assim se declara e vive de acordo. Se há alguma diferença entre o artista e uma "pessoa comum", talvez seja que o artista assume o encargo (e a responsabilidade) de construir o sentido de sua existência, o mais conscientemente que seja possível, e se for necessário transformar o mundo para isso, que assim seja, mas tudo começa numa busca íntima que, não raro, jamais chega ao fim.

Sechi afirma que não havia espaço para guardar suas obras antigas no Farol, por isso a maior parte delas ficou nos fundos, com sua família. É comum referir-se a esses trabalhos como "tralhas" que nunca conseguiu vender, apesar de todas as premiações, afinal "não combinam com a sala de estar de ninguém". Talvez haja mais do que falsa modéstia nesses comentários, pois também é possível uma leitura do fato dessas obras antigas terem ficado, conscientemente ou não, restritas aos poucos espaços de intimidade que restaram na casa: o quarto do artista e o espaço compartilhado com a família. Durante muito tempo, Sechi foi um artista isolado, preenchendo sua carência de comunicação e relacionamento humano com horas e horas de atividade criativa febril que, no limite, falhava em aliviar essas necessidades, mesmo sendo um grande êxito artístico. A Arte Postal, a ilha imaginária, se não solucionaram suas fraturas internas, ao menos o aproximaram mais da reconstrução de sua existência, um processo ainda longe do fim. Não há mais a necessidade do esforço, da dor e do isolamento necessários para a criação das obras antigas, elas não tem mais razão de ser. Mas a lembrança do que elas representam, do que elas materializam, permanece como um fantasma de uma existência à qual Sechi não quer regredir. Assim, a despeito de todos os méritos, os velhos trabalhos foram banidos para o subterrâneo da imagem poética da Sechiisland, mas permanecem velando o sono do artista, integradas ao espaço familiar que nunca as compreendeu, mas do qual elas, indubitavelmente, fazem parte.

Por fim, despedimos-nos do artista, conscientes de que essa foi apenas a primeira de muitas visitas. A Sechiisland convida ao retorno, aos novos olhares, a atenção às minúcias. Na construção de um cotidiano, de uma existência, alternativos, o "infame" José Roberto Sechi nos convida a questionar nosso cotidiano, nossa existência. Esse 
homem que, intencionalmente, tornou-se o ponto de convergência de uma infinidade de "infames" no mundo todo e nos abre as portas para a investigação e o aprendizado de um dos mundos mais singulares que existem sob o mundo que a mídia oficializa.

\section{Referências}

BACHELARD, G. A poética do espaço. São Paulo: Martins Fontes, 1993. (Coleção Tópicos).

FREIRE, C. Poéticas do processo - arte conceitual no museu. São Paulo: Iluminuras, 1999.

GIANNATTASIO, G. Infames, casos de singularidade histórica. Londrina: Projeto de Pesquisa-IC, 2004.

SECHI, J. R. Sechiisland. Rio Claro: Manifesto artesanal distribuído via correio. 2000.

\section{Apêndice}

Lista de exposições realizadas na Sechiisland's Micro Gallery, extraída do Livro de Visitantes da Galeria.

\begin{tabular}{|c|c|c|c|c|c|}
\hline Título da Exposição & $\begin{array}{l}\text { Artista ou } \\
\text { Grupo }\end{array}$ & País & Período & $\begin{array}{l}\text { N.o } \\
\text { Visit. }\end{array}$ & Observações \\
\hline $\begin{array}{l}\text { Poemas Para Mirar/ } \\
\text { Poemas Para Ver }\end{array}$ & Clemente Padín & Uruguai & $\begin{array}{l}01 \mathrm{a} \\
31 / 01 / 2003\end{array}$ & 25 & $\begin{array}{l}\text { Um dos nomes mais } \\
\text { importantes da arte postal } \\
\text { no mundo, sendo o primeiro } \\
\text { artista a trabalhar com arte } \\
\text { postal na América Latina. } \\
\text { Poeta visual, performer, } \\
\text { vídeo artista... }\end{array}$ \\
\hline $\begin{array}{l}\text { Explovisão 2003: Poema } \\
\text { Processo Hoje }\end{array}$ & Falves Silva & Brasil & $\begin{array}{l}01 \mathrm{a} \\
28 / 02 / 2003\end{array}$ & 13 & $\begin{array}{l}\text { Poeta visual histórico. Fez } \\
\text { parte da equipe criadora do } \\
\text { poema processo no final da } \\
\text { década de } 60 \text {. }\end{array}$ \\
\hline Opera di Collage & $\begin{array}{l}\text { Walter } \\
\text { Pennacchi }\end{array}$ & Itália & $\begin{array}{l}01 \mathrm{a} \\
31 / / 03 / 2003\end{array}$ & 22 & $\begin{array}{l}\text { Artista italiano bastante } \\
\text { assíduo na rede de arte } \\
\text { postal realizando um } \\
\text { trabalho com tendência } \\
\text { futurista. }\end{array}$ \\
\hline Mirada/Olhar & $\begin{array}{l}\text { Corporacion } \\
\text { Semiótica } \\
\text { Galega (Lois Gil } \\
\text { Magariños) }\end{array}$ & Espanha & $\begin{array}{l}01 \mathrm{a} \\
30 / 04 / 2003\end{array}$ & 21 & $\begin{array}{l}\text { Artista postal e poeta } \\
\text { visual galego, que se utiliza } \\
\text { amplamente de símbolos de } \\
\text { comunicação em massa em } \\
\text { seus poemas visuais. }\end{array}$ \\
\hline $\begin{array}{l}\text { Sinesteticamente ad Ogni } \\
\text { Costo/Sinesteticamente a } \\
\text { Qualquer Custo }\end{array}$ & $\begin{array}{l}\text { Grupo } \\
\text { Sinestetico }\end{array}$ & Itália & $\begin{array}{l}01 \mathrm{a} \\
31 / 05 / 2003\end{array}$ & 29 & $\begin{array}{l}\text { Grupo de performance } \\
\text { italiano, que trabalha com a } \\
\text { percepção da obra de arte a } \\
\text { partir da sinestesia. }\end{array}$ \\
\hline Berührungen/Contatos & Markus Steffen & Suíça & $\begin{array}{l}01 \mathrm{a} \\
30 / 06 / 2003\end{array}$ & 29 & $\begin{array}{l}\text { Artista suíço criador de } \\
\text { belíssimas composições } \\
\text { a partir de colagens } \\
\text { sobrepostas por textos } \\
\text { manuscritos. }\end{array}$ \\
\hline
\end{tabular}




\begin{tabular}{|c|c|c|c|c|c|}
\hline $\begin{array}{l}\text { Duhovno Ozadje Boruta } \\
\text { Hlupiča/Experiência } \\
\text { Espiritual de Borut Hlupič }\end{array}$ & $\begin{array}{l}\text { Borut Hlupič } \\
\text { Holland }\end{array}$ & Eslovênia & $\begin{array}{l}01 \mathrm{a} \\
31 / 07 / 2003\end{array}$ & 18 & $\begin{array}{l}\text { Um dos principais } \\
\text { representantes da arte } \\
\text { conceitual na Eslovênia. } \\
\text { Adepto da antroposofia } \\
\text { aliada à obra de arte. }\end{array}$ \\
\hline Brain Cell & Ryosuke Cohen & Japão & $\begin{array}{l}01 \mathrm{a} \\
31 / 08 / 2003\end{array}$ & 22 & $\begin{array}{l}\text { Artista japonês com trabalho } \\
\text { histórico na arte postal, } \\
\text { criador da famosa revista } \\
\text { alternativa Brain Cell. }\end{array}$ \\
\hline Art-Gentina & $\begin{array}{l}\text { Antonio Moreno } \\
\text { Garrido }\end{array}$ & Espanha & $\begin{array}{l}01 \mathrm{a} \\
30 / 09 / 2003\end{array}$ & 17 & $\begin{array}{l}\text { Artista catalão bastante } \\
\text { assíduo na rede de arte } \\
\text { postal. }\end{array}$ \\
\hline $\begin{array}{l}\text { 3. 'Aniversário da Revista } \\
\text { "Pense Aqui" }\end{array}$ & $\begin{array}{l}\text { José Roberto } \\
\text { Sechi }\end{array}$ & Brasil & $\begin{array}{l}01 \mathrm{a} \\
31 / 10 / 2003\end{array}$ & 30 & $\begin{array}{l}\text { Exposição de antigos } \\
\text { números do periódico }\end{array}$ \\
\hline Pinturas Tridimensionais & $\begin{array}{l}\text { José Roberto } \\
\text { Sechi }\end{array}$ & Brasil & $\begin{array}{l}21 / 02 \mathrm{a} \\
31 / 03 / 2004\end{array}$ & 30 & $\begin{array}{l}\text { Trabalhos, na maioria, } \\
\text { anteriores à criação da } \\
\text { Sechiisland }\end{array}$ \\
\hline $\begin{array}{l}\text { Electrográfica - Obra } \\
\text { Gráfica Experimental }\end{array}$ & Sílvio de Grácia & Argentina & $\begin{array}{l}01 \mathrm{a} \\
30 / 04 / 2004\end{array}$ & 17 & $\begin{array}{l}\text { Artista argentino } \\
\text { organizador de inúmeros } \\
\text { eventos de performance, } \\
\text { vídeo, arte postal e poesia } \\
\text { visual. }\end{array}$ \\
\hline Death Texts & Jim Leftwich & EUA & $\begin{array}{l}01 \mathrm{a} \\
28 / 02 / 2005\end{array}$ & 28 & $\begin{array}{l}\text { Poeta visual norte- } \\
\text { americano com trabalho } \\
\text { bastante expressivo. }\end{array}$ \\
\hline $\begin{array}{l}\text { Inter-Acciones Desde } \\
\text { Granada }\end{array}$ & $\begin{array}{l}\text { Manuel Ruiz } \\
\text { Ruiz }\end{array}$ & Espanha & $\begin{array}{l}01 \mathrm{a} \\
31 / 03 / 2005\end{array}$ & 23 & $\begin{array}{l}\text { Artista espanhol com longo } \\
\text { e bem sucedido trabalho } \\
\text { visual no qual retrata } \\
\text { principalmente os costumes } \\
\text { e imagens de sua cidade. }\end{array}$ \\
\hline Fetish Mail Art & José Nogueira & Brasil & $\begin{array}{l}01 \mathrm{a} \\
30 / 04 / 2005\end{array}$ & 27 & $\begin{array}{l}\text { Artista underground } \\
\text { paulistano. }\end{array}$ \\
\hline $\begin{array}{l}\text { Menneestä Tulevaan/Do } \\
\text { Passado Rumo ao Futuro }\end{array}$ & Paul Tiililä & Finlândia & $\begin{array}{l}01 \mathrm{a} \\
31 / 05 / 2005\end{array}$ & 40 & $\begin{array}{l}\text { Artista finlandês que } \\
\text { trabalha com computação } \\
\text { gráfica. }\end{array}$ \\
\hline $\begin{array}{l}\text { Prensa Gráfica Obsesiva o } \\
\text { El Poder de Las Imágenes }\end{array}$ & César Reglero & Espanha & $\begin{array}{l}01 \mathrm{a} \\
30 / 06 / 2005\end{array}$ & 29 & $\begin{array}{l}\text { Poeta visual e artista postal } \\
\text { catalão muito respeitado } \\
\text { na rede de arte postal, } \\
\text { organizador de inúmeros } \\
\text { eventos e um dos criadores } \\
\text { da AUMA (Action Urgent } \\
\text { Mail Art). }\end{array}$ \\
\hline
\end{tabular}


Fernandes, R. E.; Dantas, M.

\begin{tabular}{|c|c|c|c|c|c|}
\hline $\begin{array}{l}\text { Paulo Bruscky: Poemas } \\
\text { Visuais }\end{array}$ & Paulo Bruscky & Brasil & $\begin{array}{l}01 \mathrm{a} \\
31 / 07 / 2005\end{array}$ & 26 & $\begin{array}{l}\text { Um dos primeiros brasileiros } \\
\text { a trabalhar com arte postal, } \\
\text { precursor da xerox art e fax } \\
\text { art no Brasil. Participou da } \\
\text { bienal de São Paulo. }\end{array}$ \\
\hline $\begin{array}{l}\text { The Shortway of Mind/The } \\
\text { Diagonali of Presentiment }\end{array}$ & Ultima Occasio & $\begin{array}{l}\text { Sérvia e } \\
\text { Montenegro }\end{array}$ & $\begin{array}{l}01 \mathrm{a} \\
31 / 01 / 2006\end{array}$ & 36 & $\begin{array}{l}\text { Grupo multimídia sérvio } \\
\text { tendo como um dos menbros } \\
\text { Dobrica Kaperilic, um dos } \\
\text { mais importantes artistas } \\
\text { postais da Sérvia. }\end{array}$ \\
\hline $\begin{array}{l}\text { C.A.O.S - Caotica Arte } \\
\text { Ordinata Scienza }\end{array}$ & Ruggero Maggi & Itália & $\begin{array}{l}01 \mathrm{a} \\
28 / 02 / 2006\end{array}$ & 28 & $\begin{array}{l}\text { Um dos mais importantes e } \\
\text { assíduos artistas postais da } \\
\text { Itália. Trabalha também com } \\
\text { instalações e performances. } \\
\text { Participou da XVI Bienal de } \\
\text { São Paulo. }\end{array}$ \\
\hline Los Caminos & $\begin{array}{l}\text { Louirenço } \\
\text { Favari }\end{array}$ & Brasil & $\begin{array}{l}01 \mathrm{a} \\
31 / 03 / 2006\end{array}$ & 23 & $\begin{array}{l}\text { Poeta visual e artista postal } \\
\text { rioclarense }\end{array}$ \\
\hline
\end{tabular}

